\title{
Cerebellar Zones: A Personal History
}

\author{
Jan Voogd
}

Published online: 22 October 2010

(C) The Author(s) 2010. This article is published with open access at Springerlink.com

\begin{abstract}
Cerebellar zones were there, of course, before anyone noticed them. Their history is that of young people, unhindered by preconceived ideas, who followed up their observations with available or new techniques. In the 1960s of the last century, the circumstances were fortunate because three groups, in Leiden, Lund, and Bristol, using different approaches, stumbled on the same zonal pattern in the cerebellum of the cat. In Leiden, the Häggqvist myelin stain divulged the compartments in the cerebellar white matter that channel the afferent and efferent connections of the zones. In Lund, the spino-olivocerebellar pathways activated from individual spinal funiculi revealed the zonal pattern. In Bristol, charting the axon reflex of olivocerebellar climbing fibers on the surface of the cerebellum resulted in a very similar zonal map. The history of the zones is one of accidents and purposeful pursuit. The technicians, librarians, animal caretakers, students, secretaries, and medical illustrators who made it possible remain unnamed, but their contributions certainly should be acknowledged.
\end{abstract}

Keywords Cerebellum · Zones · Climbing fibers ·

Mossy fibers $\cdot$ Pattern formation

In 1954, I joined the Leiden Laboratory of Neuroanatomy as a fourth-year medical student. The laboratory was founded the year before by Professor W.J.C. Verhaart, a neurologist and neuropathologist with a passion for neuroanatomy (Fig. 1). He had just returned from Indonesia, where he spent most of his career and where he had to give up his position as a

J. Voogd $(\bowtie)$

Department of Neuroscience, Erasmus Medical Center Rotterdam,

Box 2040, 3000CA Rotterdam, The Netherlands

e-mail: janvoogd@bart.nl
Professor of Neurology at the University of Djakarta when the Dutch no longer were tolerated in an independent Indonesia. At the time, the Weigert myelin stain on celloidin-embedded material and the Marchi method for degenerated myelin, processed with osmic acid that Verhaart had smuggled out of his lab in Djakarta, were still in use. However, the real innovation for the years to come was the application of the Häggvist modification of the AlzheimerMann method. Alzheimer used this method to stain reactive glia. Material, mordanted in potassium dichromate was stained with Mann's solution, a mixture of methyl blue and eosin $[1,2]$. Fixation with chromium salts still was the routine at the end of the nineteenth century. Formalin was not introduced as a fixative till 1896 [3]. Häggqvist modified Alzheimer-Mann method for formalin fixed tissue, and paraffin-embedding [4] Häggqvist's method stains axons dark blue and the myelin sheath a bright red. Nerve cells and glia with their prolongations are stained in different shades of blue (Fig. 2). Apart from their beauty, Häggqvist-stained sections of the brain allow the distinction of myelinated fibers of a different caliber, as individual fibers or as tracts, that appear as lighter or darker stained areas, depending on the larger or smaller size of their constituent fibers.

Degenerated fibers can be recognized by the loss of their axon and the swollen, bright red myelin. Tract tracing, therefore, was feasible with the Häggqvist method. Like the Marchi technique, it depended on the visualization of degenerated myelin, but it was more reliable and, as additional advantage, degenerated fibers were embedded in an image of the entire topography of the sections studied. The great improvements in tract tracing during my career, such as the introduction of axonal degeneration techniques in the 1950s, neuron-specific labeling of axonal pathways in the 1960s, the antegrade and retrograde axonal transport methods in the 1970s, and the viral transneuronal transport 


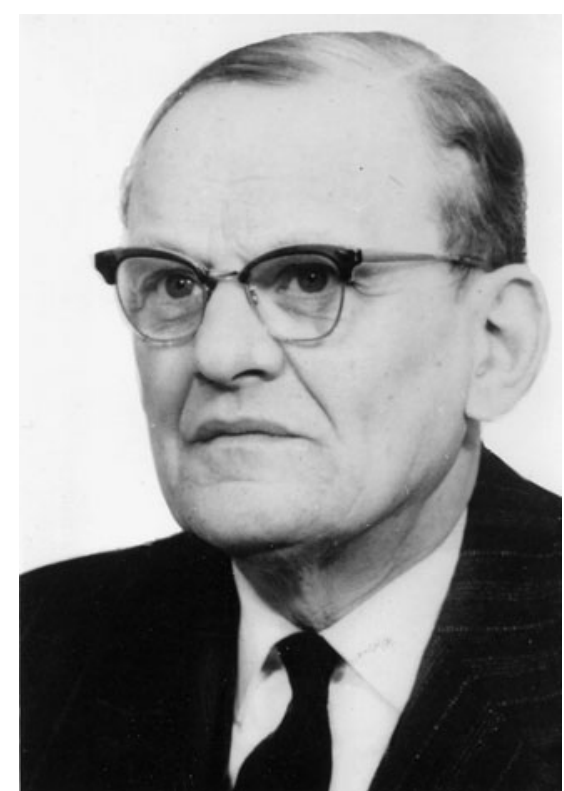

Fig. 1 Professor W.J.C. Verhaart 1889-1983

methods in the 1980s, have greatly extended our knowledge of neuronal connectivity but often lack the topographical framework that was offered by the Häggqvist method.

My reasons for joining the lab were to earn money; you got a small salary and you were exempted from paying tuition when assisting in the teaching of the microscopal anatomy course. However, Verhaart immediately pointed out that the real purpose of the lab was research and that I had to choose a subject. I started working on the cerebellum because other regions of the brain were already studied by others, all of them using the Häggqvist technique. Karel Mechelse studied the origin of descending tracts from the forebrain [5] using monkey material that Verhaart had taken with him from Djakarta. Sie Pek Giok analyzed the human brain stem and the cord [6]; the lab was one of the few places in the world where the connectivity of the human brain was studied. Herman Busch charted brain stem tracts in the cat, resulting in an outstanding description of these systems [7]. Eddy van Beusekom worked on the cat spinal cord [8], and Hans van Crevel quantified the origin of the pyramidal tract in the cat, using the degeneration rate of myelinated fibers as a tool [9]. Most of Verhaart's students became neurosurgeons, professors of neurology or pathology, or general practitioners. I was one of the few who continued as an anatomist.

For me, the lab became my social habitat; it yielded friendships based on a mutual interest and gave meaning to my life as a student, something I had missed in the brawling, alcohol-ridden atmosphere of the student unions, or in the formal routines of medical education. Grant applications or multidisciplinary research was unheard of at the time. When a new staff position was needed, Verhaart and his secretary, Mrs. Parmentier, went to the Chief Curator of the University and got the money, confident that it would be added to our budget for the next year. Verhaart's attitude to science is best expressed in a quote from his inaugural address: "A scientific investigation often seems endless, although it appears to be completed quite often. While working, you often feel that you started off from the wrong premises, hut this is only a sign of growing maturity. The research seems to go astray, but that just means that you have followed new, untrodden paths. Results are often lacking, but that is the consequence of your growing powers of discrimination, and the oblivion of your original assumptions. Research seems monotonous and tedious, but it is less so than any other kind of occupation. Between the moment of an eager start and a satisfactory ending, despair is a natural and innocent phenomenon. When you are prepared to endure these inconveniences, I will be glad to assist." Verhaart allowed you complete freedom in your research. His clinical acumen, mixed with a taste for absurdities and a vivid interest in the peculiarities of his neurological colleagues,
Fig. 2 The brachium conjunctivum of the cat. Häggqvist stain. The diagram on the right shows the origin of its medial one third from the posterior interposed $(I P)$ and fastigial $(F)$ nuclei. The coarse fibers of its middle third take their origin from the anterior interposed nucleus $(I A)$ and the dorsal part of the lateral nucleus $(L c)$, its lateral pole from the ventral part of the lateral nucleus $(L r)$ [19]. $b c$ brachium conjunctivum, unc uncinate tract, $v s t$ ventral spinocerebellar tract

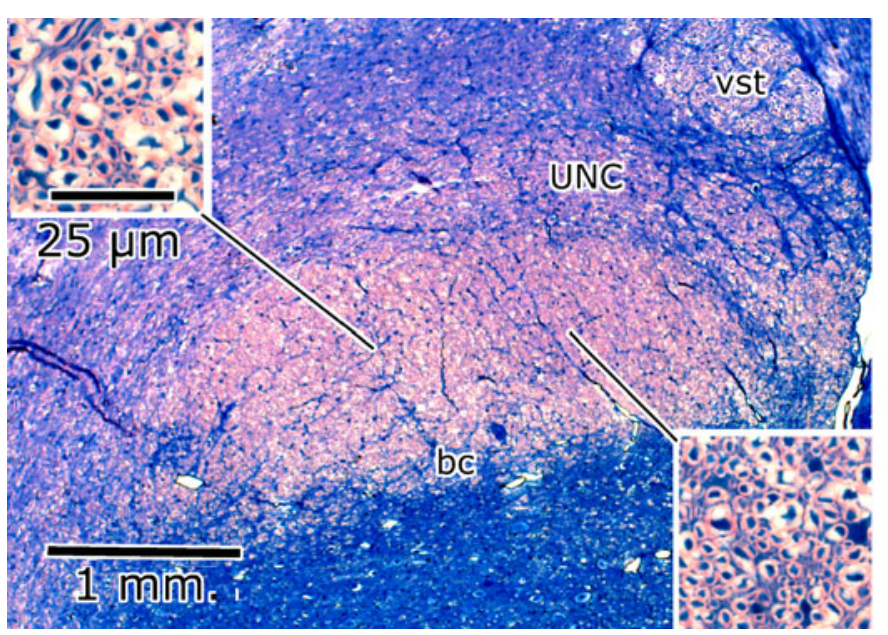

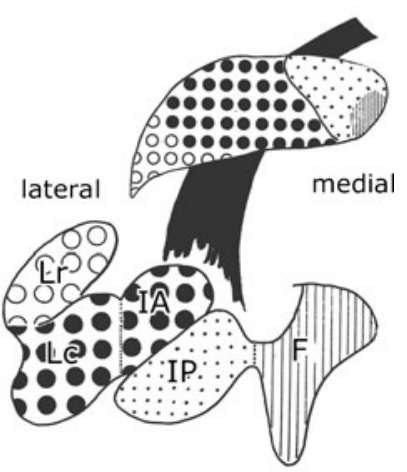


resulted in an endless stream of observation and anecdotes communicated to us during coffee time. At these memorable daily occasions, the most recent Ph.D. graduate had to vacate his chair, next to the professor, to the following candidate, who anxiously awaited Verhaart's admonishing remarks, supplemented with the tapping of his signet ring on the table and the extensive scribbled annotations on the chapter he had submitted the day before.

My choice of the cerebellum also was made because Verhaart recently had observed the presence of medial, small caliber and lateral, larger caliber fiber divisions in the brachium conjunctivum of the cat and other mammals [10] (Fig. 2). It would be my task to determine the origin of the two divisions. I soon discovered that the medial one third of the brachium conjunctivum of the cat took its origin from the caudal part of the interposed nucleus, and the lateral two thirds from its rostral part and the lateral cerebellar nucleus (Fig. 3). However, the anterior and posterior interposed nuclei were not recognized as separate nuclei at the time. The prevailing concept of the cerebellar nuclei, introduced by Brunner [11], was that in lower mammals, such as the cat, they formed a single mass, divided into medial, interposed, and lateral parts by indentations on the surface. Only in higher primates, the division into the four classical nuclei of Stilling would become apparent.

These ideas on the subdivision of the cerebellar nuclei were shared by Jan Jansen and Alf Brodal from the Oslo Department of Anatomy, the leading authorities on the anatomy of the cerebellum in the decades following the Second World War [12, 13] (Fig. 3). In 1940 and 1942, they published papers on the corticonuclear projection of the cerebellum in cat, rabbit, and monkey using the Marchi method [14, 15]. They concluded that this system was organized into three parallel zones: the hemivermis, projecting to the ipsilateral fastigial and vestibular nuclei; the lateral or hemispheral zone, projecting to the lateral cerebellar nucleus; and an intermediate zone, connected with the interposed nucleus (Fig. 4a).

When I perused the literature, I found out that a division of the interposed cerebellar nucleus into anterior and posterior nuclei had been proposed before by Weidenreich [16] and by Ogawa [17], who coined the names anterior and posterior interposed nuclei. Ogawa made his observations in Pinnipedia and Cetacea, where he found that the posterior interposed nucleus by far exceeds the other cerebellar nuclei in size. This made me wonder about the possible differences in the corticonuclear projection to these nuclei, and I started making lesions of the cerebellar cortex of the cat and tracing the degenerated Purkinje cell axons with the Häggqvist method. I didn't neglect the afferent systems of the cerebellum, and I started a rather ambitious program to trace them with the same method. A large experimental material was already available from the analysis of fiber systems in the cat brain stem by Herman Busch, who acted as my scientific mentor at the time [18].

When I was mapping hundreds of Häggqvist-stained sections under the microscope, I was struck by a myeloarchitectonic division of the folial white matter. In transverse sections, compartments with relatively large myelinated axons were separated by narrow bands of small fibers (the "raphes"), and this pattern was repeated in each successive lobule (Figs. 5 and 6). Herman Busch was quite impressed when I showed the sections to him, and we rejoiced, smoking till deep in the night, sitting in the old leather chairs that had once belonged to Einthoven, Nobel prize winner and discoverer of the electrocardiogram.

When traced, the borders between the white matter compartments merged with the borders of the cerebellar
Fig. 3 Prof. Jan B. Jansen (1898-1984) and Prof. Alf Brodal (1910-1988). Courtesy of Per Brodal
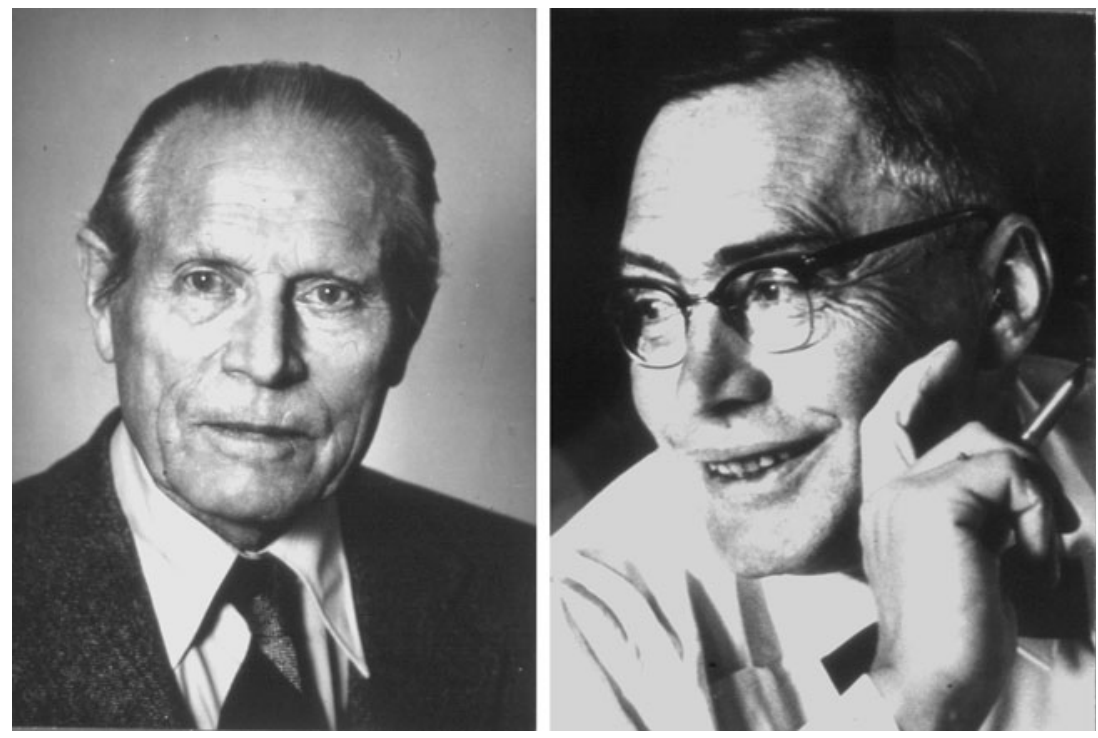

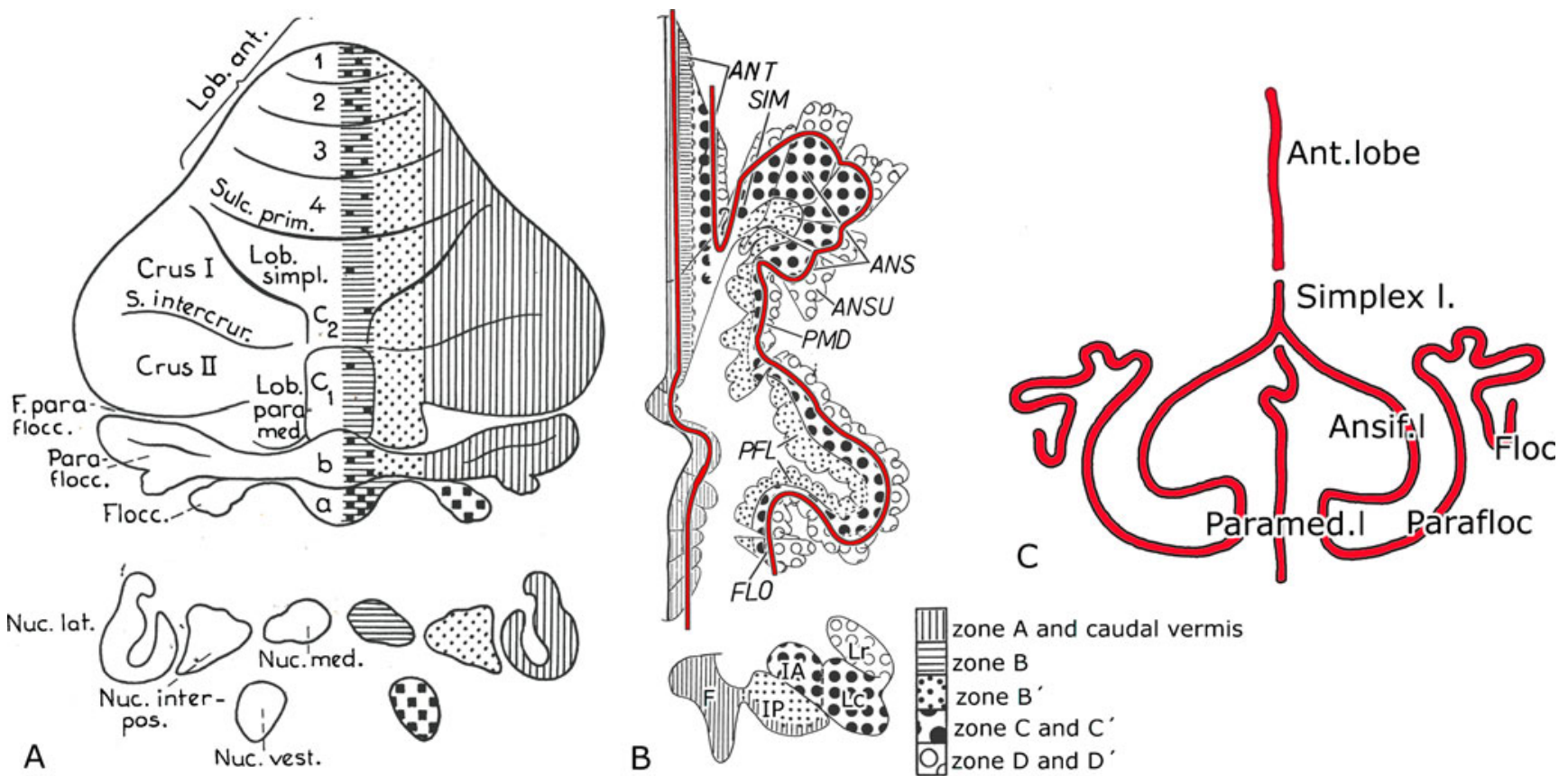

Fig. 4 A Diagram of the corticonuclear projection of the cerebellum, showing the vermal, intermediate, and lateral zones of Jansen and Brodal [15]. Nomenclature of the lobules according to Bolk [20]. B Diagram of the flattened cerebellar cortex of the cat showing the corticonuclear projection. From Voogd [19]. The contoures (red) lines indicate the direction of the folial chains of vermis and hemisphere. $\mathbf{C}$

Stick diagram of the folial chains of the mammalian cerebellum. Bolk [20]. ANS(if.) ansiform lobule, $A N S U$ ansula, $A N T$ anterior lobe, $F$ fastigial nucleus, FLOC flocculus, $I A$ anterior interposed nucleus, $I P$ posterior interposed nucleus, $L c$ dorsal part lateral nucleus, $L r$ ventral part lateral nucleus, $P F L$ paraflocculus, $P M D$ paramedian lobule, SIM lobulus simplex

nuclei, allowing the conclusion that these compartments served as channels for the Purkinje cell axons of longitudinal cerebellar zones to a particular cerebellar nucleus. I could prove this idea from my experiments on the cortico-

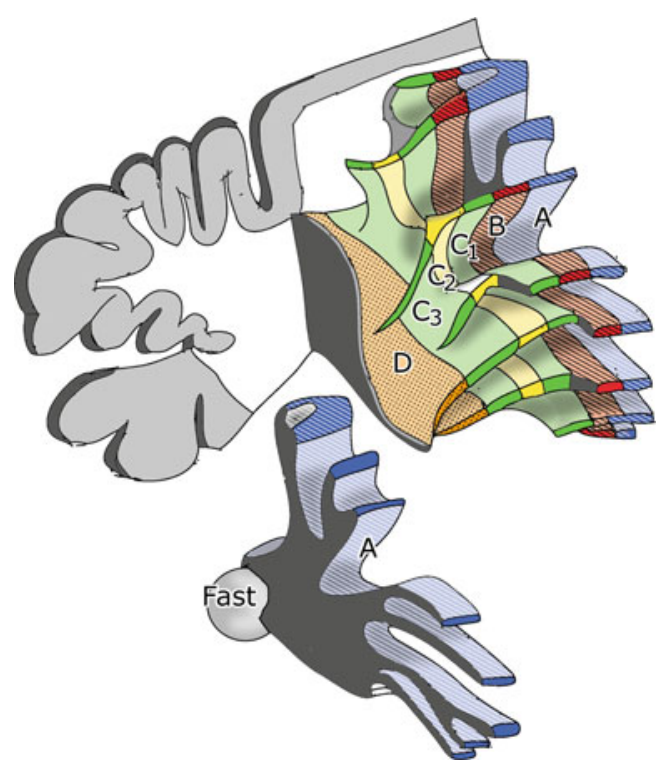

Fig. 5 Reconstruction of the white matter compartments of the anterior lobe of the ferret cerebellum. Compartment A with its target nucleus, the fastigial nucleus, is illustrated at the bottom of the figure nuclear projection and summarized these findings in a diagram [19] (Fig. 4b). This diagram later became greatly modified, but the distinction of the $\mathrm{A}$ and $\mathrm{B}$ zones in the vermis, A projecting to the fastigial nucleus and $\mathrm{B}$ to Deiters' lateral vestibular nucleus, and of the presence of three zones in the paraflocculus, indicated as $\mathrm{B}^{\prime}$ (the present $\mathrm{C}_{2}$ zone), $\mathrm{C}\left(\mathrm{D}_{1}\right)$, and $\mathrm{D}\left(\mathrm{D}_{2}\right)$, have withstood time.

In fact, my diagram still closely corresponded to Brodal and Jansen's ideas; only, each of their vermal, intermediate, and lateral zones could be divided into two subzones. The main difference with their diagram was a topological one. In my diagram, the zones of the hemisphere follow the long axis of its folial chain. The term "folial chain" was introduced by the Dutch anatomist Lodewijk Bolk in a comparative anatomical study of the gross morphology of the mammalian cerebellum, for a sequence of parallel folia [20]. He concluded that the cerebellum can be visualized as three parallel folial chains of the vermis and the two hemispheres. In the anterior lobe and the lobules simplex, the folia of vermis and hemispheres are continuous, and the three folial chains cannot be distinguished. Caudal to the lobules simplex, the deep paramedian sulcus intervenes between the folial chains of vermis and hemispheres. The folial chain of the hemisphere makes two loops: the rostral folial loop of the ansiform lobule and the caudal loop of the paraflocculus. The axis of the folial chain follows these 
Fig. 6 Borders of white matter compartments ("raphes": arrowheads) at the midline, between $\mathrm{A}$ and $\mathrm{B}$ compartments, and between $\mathrm{C}_{1}, \mathrm{C}_{2}$, and $\mathrm{C}_{3}$ compartments. Purkinje cell axons of different compartments are illustrated at higher magnification in the lower right panels
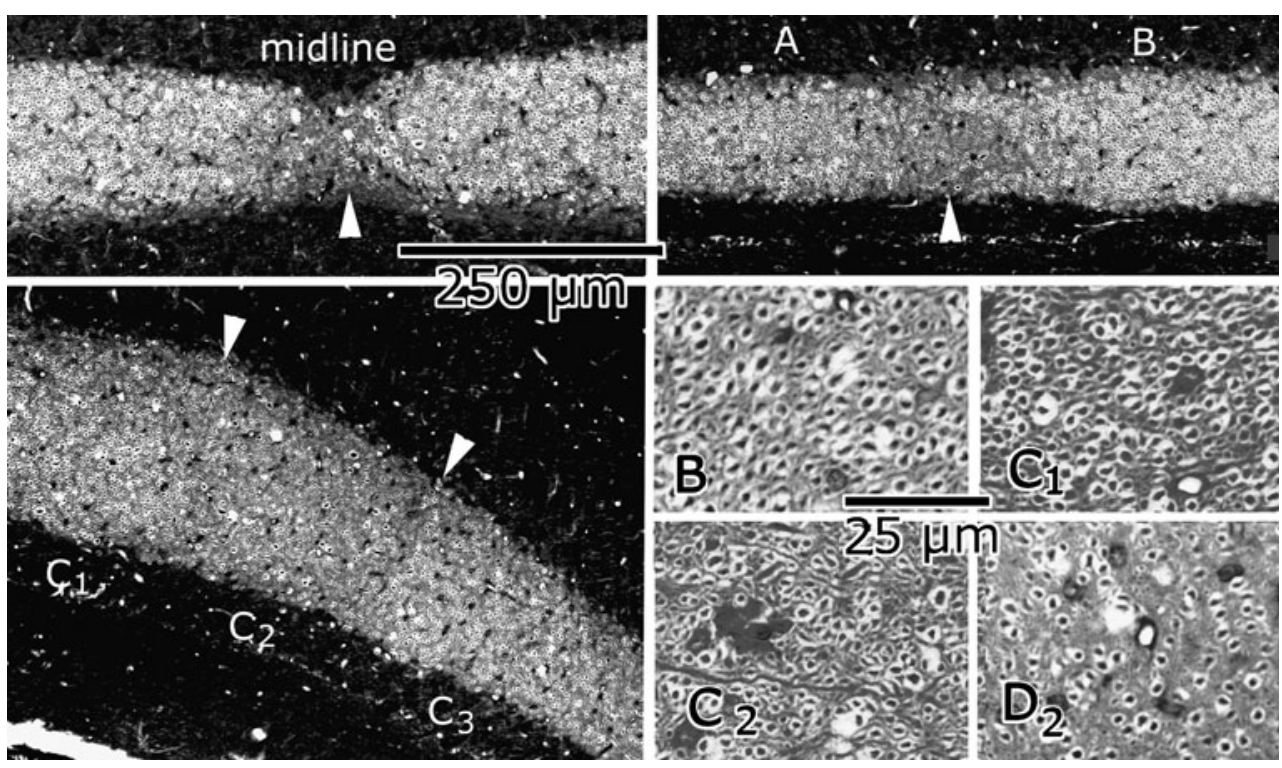

curvatures. In the diagram of Jansen and Brodal (Fig. 4a), the border between the intermediate and lateral zones cuts through the folial chain of the hemisphere; the entire paramedian lobule and the medial part of the paraflocculus are included in the intermediate zone, and the lateral part of the folial loop of the paraflocculus belongs to the lateral zone. The observation that the Purkinje cell zones follow the curves and bends of the folial chain of the hemisphere also is evident from the reconstructions and the whole mounts of the cerebellum from later studies using histochemistry, genetical engineering, or birth dating of Purkinje cells to visualize the zones (Fig. 7). For Bolk, the folial chains were a series of macroscopically visualized folia. He never used a microscope. For me, each of them represented a long and narrow cortical sheet, divided into lobules and folia by transverse fissures and sudden changes in direction of the chain. In the center of the loops of the ansiform lobule and the paraflocculus, the cortex always is interrupted, and white matter comes to the surface. In the cat, white matter in the bottom of the paramedian sulcus entirely separates the cortex of the vermis from the hemisphere.

In 1964, I finished my medical studies. During the last of my internships, I was offered a residency in dermatology that I had almost accepted when Verhaart offered me a permanent position in his lab. I left clinical medicine, never to return. I defended my Ph.D. thesis on "The cerebellum of the cat" [19] with honors in the same year and pursued my experiments on afferent connections of the cerebellum, now using Nauta's method for selective silver impregnation of degenerated axons. Interestingly, Walle Nauta started his quest for selective silver impregnation of degenerating axoplasm before the war in the Department of Anatomy, in the same building as our lab, under Professor Dankmeyer [21]. When the Germans closed Leiden University in 1941, as a "hornet's nest of ideological subversion," he continued his studies in Utrecht.

One may have expected that I would have written a series of papers on the basis of my thesis, but that is not what I did. A printed thesis was considered sufficient at the time, a misconception that I did not correct until much later. With Joost van Rossum [22], I started a study of the rabbit cerebellum that resulted in the demonstration that spinocerebellar fibers terminate in a number of parasagittal aggregates of mossy fiber terminals in the granular layer. This type of distribution was confirmed for most other mossy fiber systems [23-26]. These observations slumbered for a long time, until they were taken up again in the next century by Tom Ruigrok and Angelique Pijpers [27], who showed the precise topographical relationship between longitudinal mossy fiber terminal aggregates, climbing fiber terminal fields, and the zebrin pattern. A similar mossy fiber pattern was found for the termination of the spinocerebellar tracts by Jan Vielvoye in the chicken [28]. An analysis of the development and the adult compartmentalization of the chicken cerebellum was started by Hans Feirabend.

One of the most interesting accidental findings of this period was on the olivocerebellar projection. A student, van Beest, was making lesions in the reticular formation of the cat to study reticulocerebellar pathways, but his electrodes missed their target and ended up in the inferior olive. Surprisingly, the degenerated olivocerebellar fibers from different olivary subnuclei used particular white matter compartments in the contralateral cerebellum to reach the cortex of a longitudinal zone. The white matter compartments, therefore, serve as common channels, used both by afferent olivocerebellar and efferent Purkinje cell axons of a particular longitudinal zone. 


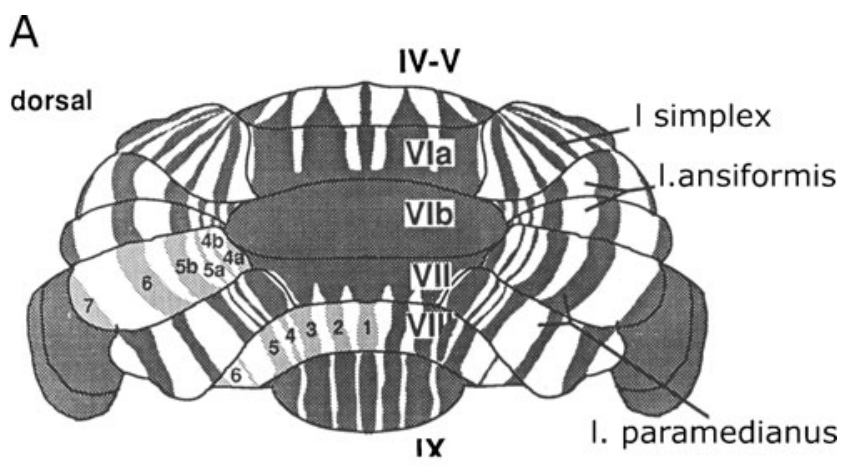

B

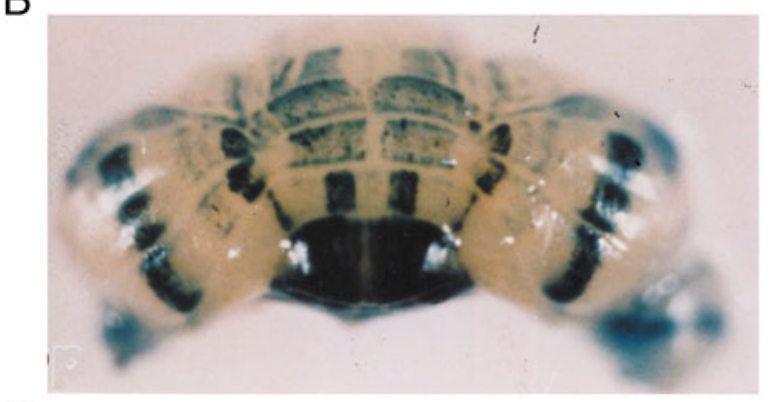

C

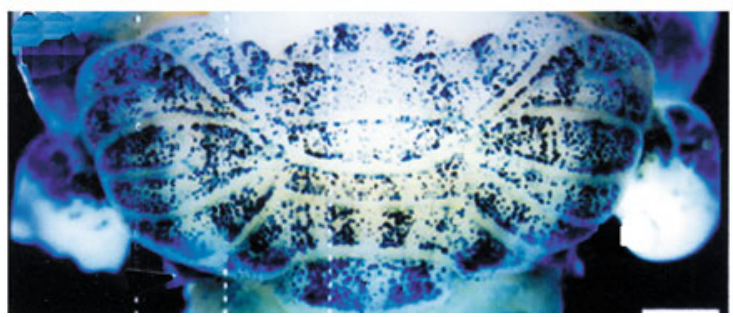

Fig. 7 a Diagram of the zebrin-positive and -negative Purkinje cell bands of the cerebellum of the mouse. Dorsal view. Zebrin-positive bands are identified by their numbers. Reproduced from Eisenman and Hawkes [73]. b Whole mount of L7-LacZ banding pattern in 11-day postnatal mouse, produced by manipulation of the promoter. Caudal view. Reproduced from Oberdick et al. [94]. c Distribution of Purkinje cells in mouse, born on E 11.5, shown at 20 days postnatally. Purkinje cells in empty strips are born either earlier or later. Reproduced from Hashimoto and Mikoshiba [92]

The analysis of the white matter compartments progressed to a semifinal stage, using Häggqvist-stained sections of the ferret cerebellum. Ferrets were obtained from a neighboring influenza lab, where they were exsanguated at the end of an experiment. Our animal caretaker, Mr. Rovers, got them there for nothing and reanimated them. Rovers had been a sailor on the Dutch merchant navy, torpedoed several times during the Second World War, and a fisherman in his later years. His experience in transporting cattle from South America made him a likely candidate for the job. He took care of our large menagerie: cats, monkeys, and ferrets, but also capybaras, tupaias, crocodiles, parrots, chickens, and goats. The latter were slaughtered, the heads perfused, and the rest consumed as sateh kambing, an Indonesian specialty, with everybody gathering around the lab's barbecue. Of a bear, only the brain arrived. It was bought for us from a local Greek gypsy by Azarias Karmanlidis, a welcome guest of the department, who took Gerda, our best technician, with him back to Thessaloniki as his wife. Irena Grofóva, a guest from Prague, who stayed with us during the Russian invasion of Tchekoslovakia in 1968, studied its coarse-fibered pallidofugal system with the Häggqvist method [29].

In ferrets, the white matter compartments were very clear and could be correlated with the efferent corticonuclear and some of the afferent olivocerebellar projections of particular zones. The diagram in Fig. 6 depicts the zonal organization of the anterior lobe of the ferret cerebellum, documented more fully in my 1969 paper [30], which is republished in the current issue of The Cerebellum $[X]$. The A and $\mathrm{B}$ zones, again, could be recognized. In later studies, the extent of the B zone was found to be limited to the anterior lobe with the simple lobule and the pyramis (lobule VIII). In the hemisphere, the $\mathrm{C}_{1}$ and $\mathrm{C}_{3}$ zones were connected with the anterior interposed nucleus, the $\mathrm{C}_{2}$ zone with the posterior interposed nucleus. $\mathrm{D}_{1}$ and $\mathrm{D}_{2}$ zones could be distinguished in the paraflocculus and the adjacent paramedian lobule. They were found to be connected with the caudal and rostral portions of the lateral cerebellar nucleus, respectively. The A and B compartments contained olivocerebellar fibers from the caudal pole of the medial and the dorsal accessory olive, respectively; the precise origin of olivocerebellar pathways to other zones could not yet be determined.

An interesting observation was the systematic difference in fiber caliber of the Purkinje cell axons of the different white matter compartments (Fig. 5). In the $\mathrm{B}, \mathrm{C}_{1}, \mathrm{C}_{3}$, and $\mathrm{D}_{2}$ compartments, these fibers are distinctly larger than those of the $\mathrm{C}_{2}$ and $\mathrm{D}_{1}$ compartments. These differences presage and partially correspond with the more recently established histochemical, developmental, and connectional differences between Purkinje cells of the different longitudinal zones [31, 32].

The observation that olivocerebellar fibers from particular subnuclei are distributed in longitudinal zones was at variance with the current opinion. Their termination as climbing fibers wasn't even known at the time. The Nauta method did not stain these terminals, and it had to wait until Desclin [33], a histologist from the Université Libre de Bruxelles, using a modified Nauta (Fink-Heimer) technique and short survival times, demonstrated that all climbing fibers take their origin from the inferior olive. The last systematic study of the olivocerebellar projection was by Brodal in 1940 [34]. He mapped retrograde changes in neurons of the inferior olive in immature cats and rabbits (the modified Von Gudden method). The diagram, summarizing his findings in the cat, is organized in a lobular fashion (Fig. 8a). Apart from the caudal pole of the medial 
A
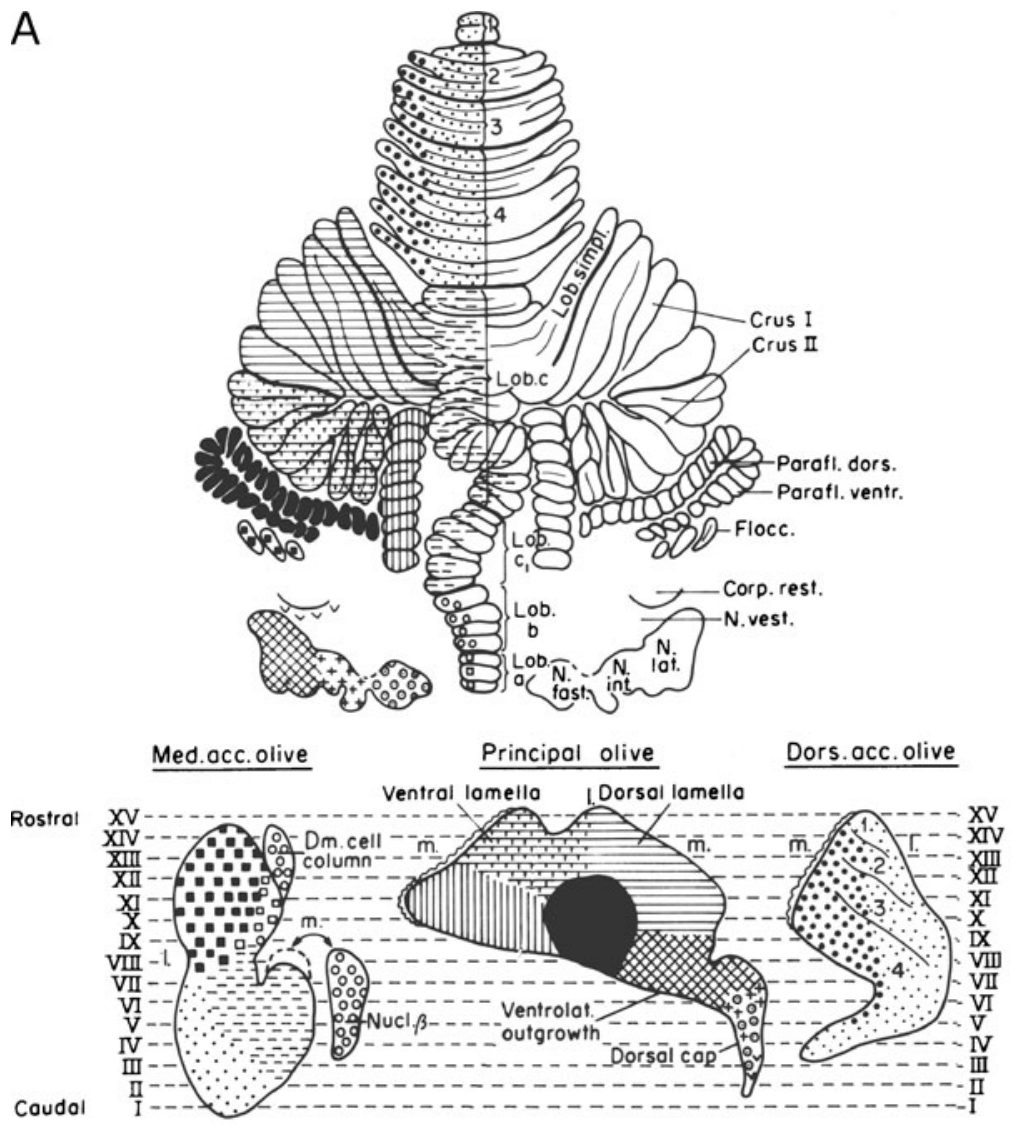

XI

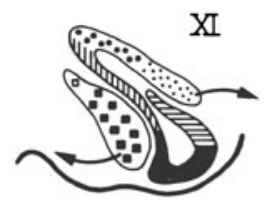

Fig. 8 a Olivocerebellar projection shown in diagrams of the flattened cerebellar cortex and the flattened inferior olive of the cat. The method used to flatten the olive is shown in the bottom diagram. Reproduced from Brodal [34]. b Similar diagrams of the olivocerebellar projection in the cat from Groenewegen [36]. ANSl Ansiform lobule, $B$ group beta, $D$ dentate (lateral) nucleus, $D A O$ dorsal accessory olive, $d c$ dorsal cap, $D e i$ lateral vestibular nucleus of Deiters, $d l$ dorsal lamina principal

accessory olive and the lateral half of the dorsal accessory olive that both project to the vermis of the anterior lobe, all lobules receive their projections from single areas in the inferior olive.

When the axonal transport methods using tritiated amino acids became available, Henk Groenewegen started his investigation of the olivocerebellar projection in the cat $[35,36]$. After he obtained his Leiden PH.D, he switched Universities and subject, continuing in the Department of Anatomy of the Free University in Amsterdam and devoting himself to a life in the basal ganglia. Groenewegen was not the first to apply autoradiography of tritiated amino acids to this problem; he was preceded by Jacques Courville [37], but he had the advantage of using
B
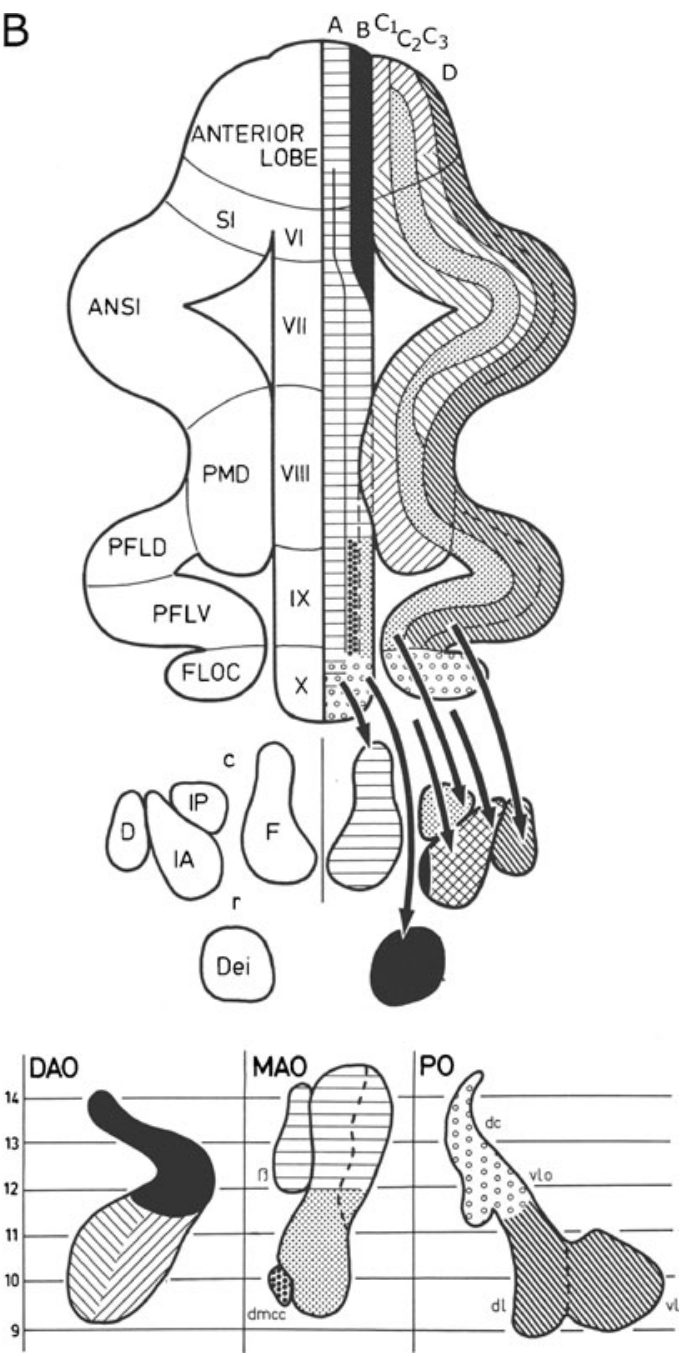

olive, $d m c c$ dorsomedial cell column, FLOC flocculus, IA anterior interposed nucleus, $I P$ posterior interposed nucleus, $l$ lateral, $m$ medial, $M A O$ medial accessory olive, PFLD dorsal paraflocculus, PFLV ventral paraflocculus, $P M D$ paramedian lobule, $P O$ principal olive, SI lobulus simplex, $V I-X$ lobules VI-X of Larsell, $v l$ ventral lamina principal olive, vlo ventrolateral outgrowth

the compartmental subdivision of the white matter in the interpretation of his findings. When the diagrams of the olivocerebellar projection of Groenewegen and Brodal are compared (Fig. 8), it is immediately clear that single subnuclei of the inferior olive project to longitudinal zones that extend over multiple lobules, in some cases, over the entire rostrocaudal length of the cerebellum. The olivocerebellar projection is arranged as a longitudinal zonal and not as a lobular pattern. Groenewegen, moreover, showed collateral projections of the olivocerebellar fibers to the cerebellar target nuclei of the zones. Later, these collateral projections were verified with electron microscopy by Han van der Want $[38,39]$ and mapped in greater detail in the rat by Tom Ruigrok [40]. 
The zonal organization of the corticonuclear projection was extensively studied by Duane Haines and his collaborators, extending the zonal concept to prosimians, monkeys, and marsupials [41] and by Frieda Bigare in the cat. Frieda Bigaré was a Belgian biologist who assisted me for a long time in the teaching of neuroanatomy in the Flemish-speaking Free University (Vrije Universiteit) of Brussels, where I spend 1 day each week for 15 years. The Université Libre de Bruxelles is a non-denominational institute, founded in the nineteenth century by the Jewish community and by free masons. Originally, it was Frenchspeaking; the Walloons were more liberal than the staunchly Roman Catholic Flemish, but as an aftermath of the student uprisings in the 1960s of the last century that concentrated on the language problems in Belgium, the Université Libre was split into Flemish and Frenchspeaking institutes. They were short of Flemish teachers, so I came in and got my first professorship. Flemish and Dutch is much alike, but still, the students could not always understand my jokes. They liked to learn things by heart, though, and thus formed an ideal audience for an anatomist, very different from my experience in Leiden, where students were convinced that comprehension, rather than knowledge of the data, was the core business of higher education.

In her thesis, Frieda Bigaré mapped the corticonuclear projection in the cat from injections with retrograde tracers in the cerebellar nuclei [42]. Her findings were published and combined with Groenewegen's data on the zonal organization of the olivocerebellar projection in a paper where we introduced the term "cerebellar module" for the ensemble of a Purkinje cell zone, its climbing afferents, and its target nucleus [43]. A module also would include the nucleo-olivary pathway [44]. The reciprocal nature of this connection was shown by Ruigrok in the rat [45].

One of my main concerns at the time was how Jansen and Brodal would react to my ideas. I first met Jan Jansen in 1969, when he visited Leiden to receive an honorary degree. My fiancée, Evelien, and I showed him around. He was a friendly and open person, a real Viking, a national Norwegian hero for his role in the Norwegian resistance. He showed great interest in my work, including it in his review of cerebellar anatomy from 1972 [46]. Brodal was a different matter. Our findings undermined the opinions he had held for the last 20 years. He was an outstanding scientist, but fairly rigid and difficult to approach. It was at a visit to Oslo in the late 1970s that he seemed to accept my views, which he acknowledged in his review of the olivocerebellar projection from 1980 [47]. We even became friends of a sort. I will never forget the symposium and the great, emotional dinner where Brodal assembled his family, friends, and colleagues, not so long before his death from a prostate carcinoma in 1988.
I presented my views on the longitudinal zonal organization of the cerebellum at the 1969 meeting organized and published by Rudolfo Llinás [48] in the AMA building in Chicago, where his lab was located at the time. My first visit to the USA and to an international meeting was a memorable occasion where I first met Olov Oscarsson (Fig. 9). For some time, Oscarsson had been working on the electrophysiology of spinocerebellar tracts, often using preparations where he stimulated the dissected tracts in the spinal cord. He first published on spino-olivary climbing fiber systems (SOCPs) using the same method, in 1967 and 1968 [49, 50], and summarized his findings on the sagittal organization of the SOCPs to the anterior lobe of the cat, activated by stimulation of the ventral, dorsal, lateral, and dorsolateral funiculi of the cord in a lecture at the symposium (Fig. 10) [51]. We immediately recognized that that we studied identical systems, and in his later studies, Oscarsson adopted my nomenclature for the zones. Oscarsson's work always was accurate, reliable, and devoid of speculations, properties that still characterize the work of the Lund group of cerebellar neurophysiologists today. This meeting contributed much to my confidence in my work, where my imagination sometimes ran wild in order to fill the gaps between my observations. Oscarsson was a modest but, in his research, assertive person. He inspired his students who were, and still are, among the most innovating cerebellar physiologists. We met fairly often at meetings or in Lund, where Evelien and I stayed with Olov and his wife Gerd till his untimely death in 1996. Fortunately, the contacts with Gerd Oscarsson remained.

Oscarsson and his co-workers greatly extended our knowledge of the zones. With Gert Andersson, he first described microzones in the $\mathrm{B}$ zone of the cat cerebellum:

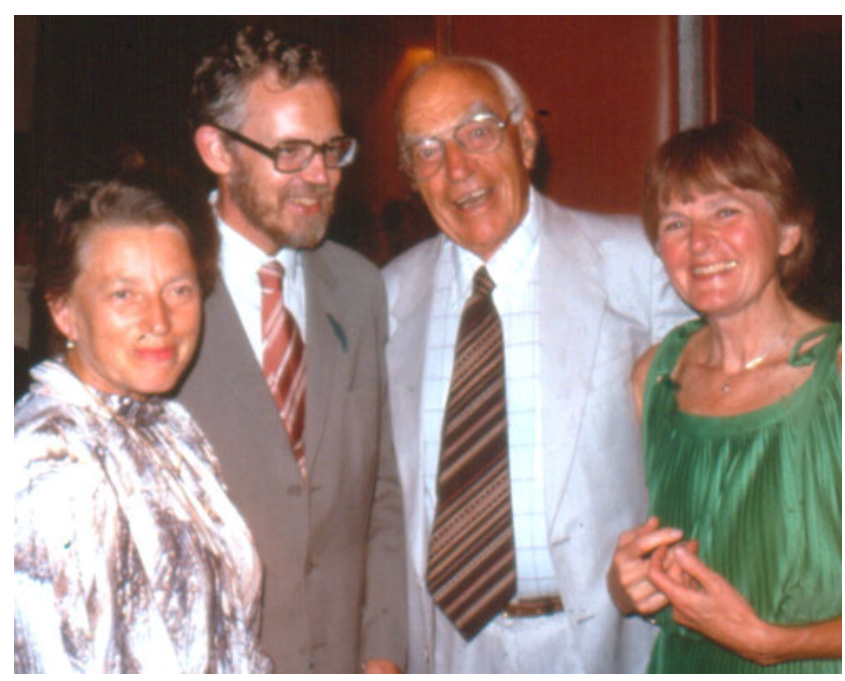

Fig. 9 Olov Oscarsson (1931-1996) with Lady Helena (left) and Sir John Eccles and his wife, Gerd Oscarsson, taken in Canberra in the 1960s. Courtesy of Gerd Oscarsson 


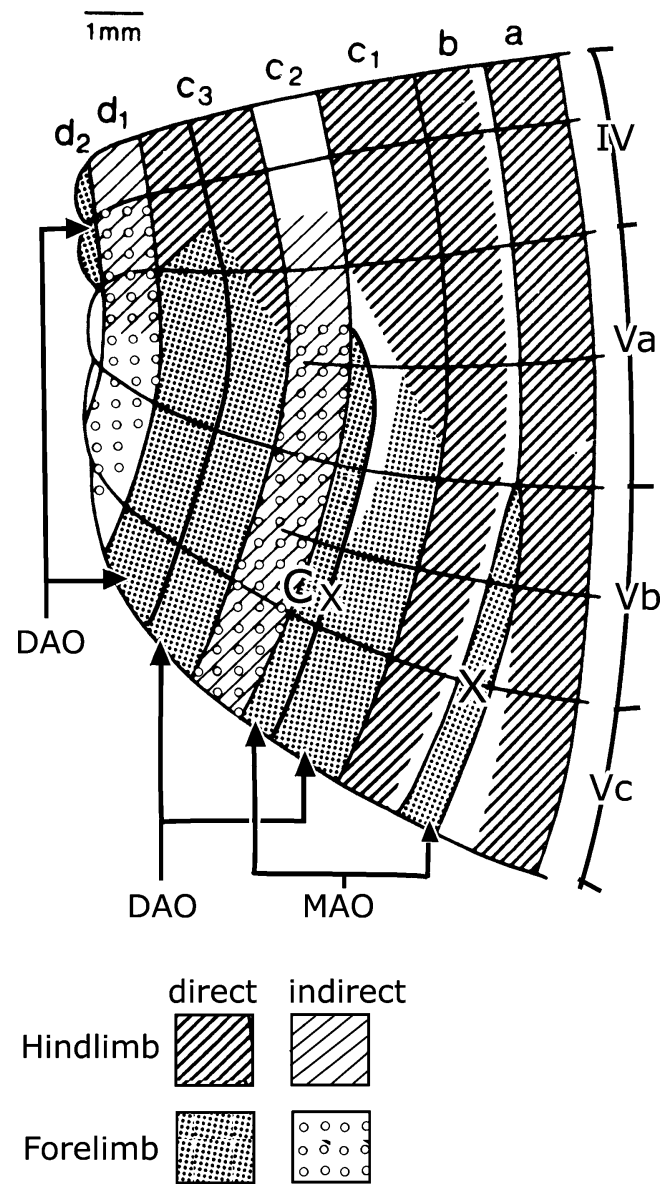

Fig. 10 Map of the anterior lobe of the cerebellum of the cat, showing the zonal projection of the dorsal funiculus spino-olivocerebellar climbing fiber path. The somatotopical organization of the zones is shown; indirect projections contain two or more synapses. The double nature of the $\mathrm{C}_{3}$ zone and the transverse branching of climbing fibers between the zones are indicated. Modified from [54]

narrow longitudinal strips of Purkinje cells that receive climbing fibers sharing the same peripheral receptive field [52]. Gert Andersson also identified an additional X zone, located between the A and $\mathrm{B}$ zones of the anterior lobe [53] (Fig. 10). Ekerot and Larson demonstrated that the $\mathrm{C}_{3}$ zone consists of two subzones by showing the double, mirrored somatotopical organization of its microzones $[54,55]$. The same authors found systematic climbing fiber branching between the $\mathrm{X}$ and lateral $\mathrm{C}_{1}$ zones, the medial $\mathrm{C}_{1}$ zone and the medial $\mathrm{C}_{3}$ zone, and the lateral $\mathrm{C}_{3}$ zone and the $\mathrm{d}_{2}$ or $\mathrm{Y}$ zone in the extreme lateral part of the anterior lobe [56] (Fig. 10). The $\mathrm{X}$ zone also could be recognized in Häggqvist-stained material. Originally, its small Purkinje cell axons were not recognized and included in the raphe separating the $\mathrm{A}$ and $\mathrm{B}$ zones (Fig. 7). The $\mathrm{X}$ zone receives its climbing fibers from the junction of the rostral and caudal halves of the medial accessory olive [57] and projects to the interstitial cell groups, a cerebellar nucleus located between the fastigial and posterior interposed nuclei
$[58,59]$. The "lateral $C_{1}$ zone" that shares its climbing fiber input with the $\mathrm{X}$ zone remains rather enigmatic. In my opinion, it should be included in the $\mathrm{C}_{2}$ zone that receives its climbing fibers from the adjacent rostral medial accessory olive. Moreover, $\mathrm{C}_{2}$ and $\mathrm{X}$ both are characterized by the small caliber of their Purkinje cell axons. The $d_{2}$ zone of Ekerot and Larson receives its climbing fibers from the rostral dorsal accessory olive and projects to the lateral pole of the anterior interposed nucleus. In these respects, it is very similar to the $\mathrm{C}_{1}$ and $\mathrm{C}_{3}$ zones. It may correspond to the $\mathrm{D}_{0}$ zone of the rat [60] that is located between the $\mathrm{D}_{1}$ and $\mathrm{D}_{2}$ zone in the hemisphere [32, 61, 62] (Fig. 11). Whatever its name, the localization of a Purkinje cell zone

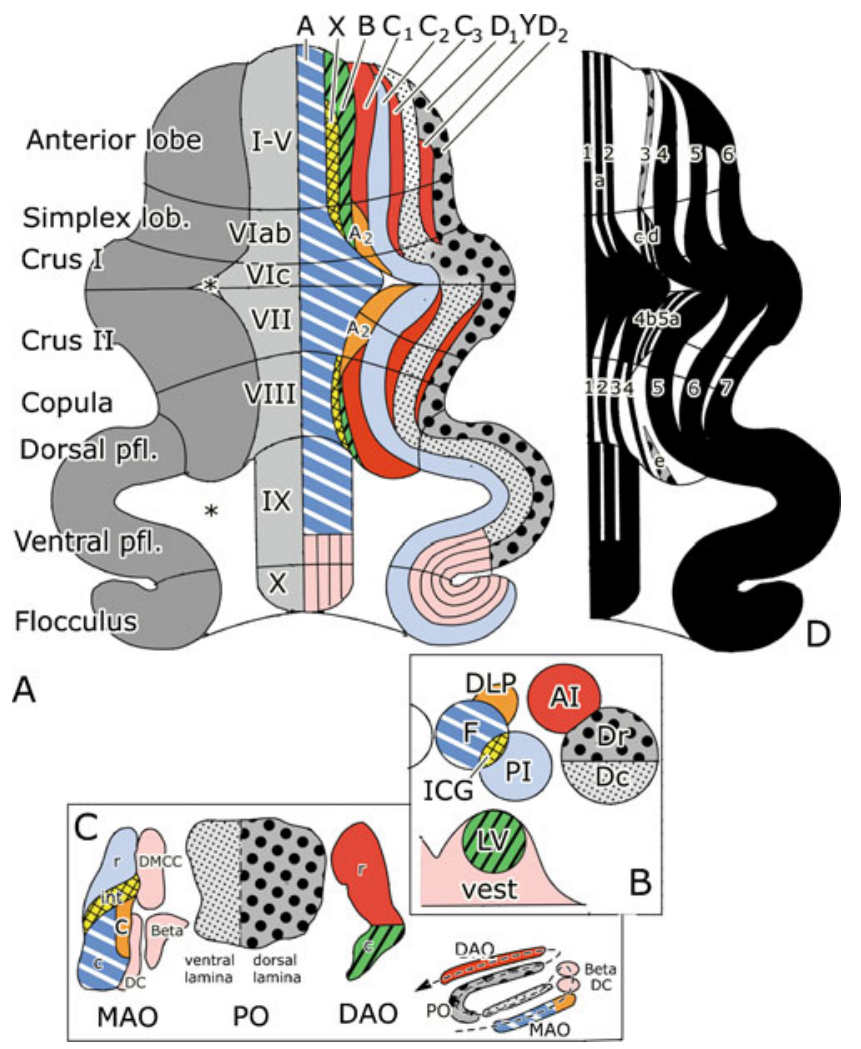

Fig. 11 Diagram of the zonal organization of the cerebellum of the rat. a Diagram of the flattened cerebellar cortex; the Purkinje cell zones are shown in the right half of the diagram. The $\mathrm{A}_{2}$ zone and the $\mathrm{Y}$ zone have not been identified in the monkey cerebellum. b Cerebellar and vestibular target nuclei of the Purkinje cell zones. c Diagram of the flattened inferior olive, showing subnuclei with projections to the Purkinje cell zones and their target nuclei. d Diagram of the zebrin-positive and -negative bands. $A-D_{2}$ Purkinje cell zones $\mathrm{A}-\mathrm{D}_{2}, 1-7$ zebrin-positive bands $\mathrm{P}+1-7, A I$ anterior interposed nucleus, Beta cell group beta, $c$ caudal (MAO or DAO), $C$ subnucleus $\mathrm{C}$ of the caudal MAO, $D A O$ dorsal accessory olive, $D c$ caudal subnucleus of the dentate nucleus, $D C$ dorsal cap and ventrolateral outgrowth, $D L P$ dorsolateral protuberance of the fastigial nucleus, $D M C C$ dorsomedial cell column, $D r$ rostral subnucleus of the dentate nucleus, $F$ fastigial nucleus, $i$ intermediate MAO, ICG interstitial cell groups, $L V$ lateral vestibular nucleus, $M A O$ medial accessory olive, $P I$ posterior interposed nucleus, $P O$ principal olive, $r$ rostral (MAO or DAO), vest vestibular nuclei 
with a projection to the anterior interposed nucleus, in between two $\mathrm{D}$ zones projecting to the dentate, means that a strict separation of Brodal and Jansen's intermediate and lateral zones does not exist.

In the 1960s, David Armstrong started his cerebellar research in the Department of Physiology of the University of Bristol. He stimulated and recorded the axon reflex of the climbing fibers from the cerebellar cortex of the cat and thus produced an accurate map of the mirrored, zonal organization of anterior lobe and the paramedian lobule [63, 64] (Fig. 12). The map also showed transverse branching between the putative $\mathrm{C}_{1}$ and $\mathrm{C}_{3}$ zones, thus preceding Ekerot and Larson's [56] work, and demonstrated the common origin of the climbing fibers innervating the $\mathrm{C}_{1}, \mathrm{C}_{2}$, and $\mathrm{C}_{3}$ zones in the anterior and posterior cerebellum. His studies culminated at the time in the charting of the entire olivocerebellar projection of the cerebellum of the cat, based on antidromic stimulation from the cortex and recording from the inferior olive [65] (Fig. 13). Interestingly, collateralization of olivocerebellar fibers again was used, but now mapped with axonal tracers, during my stay in Bristol in 2000, when David Armstrong

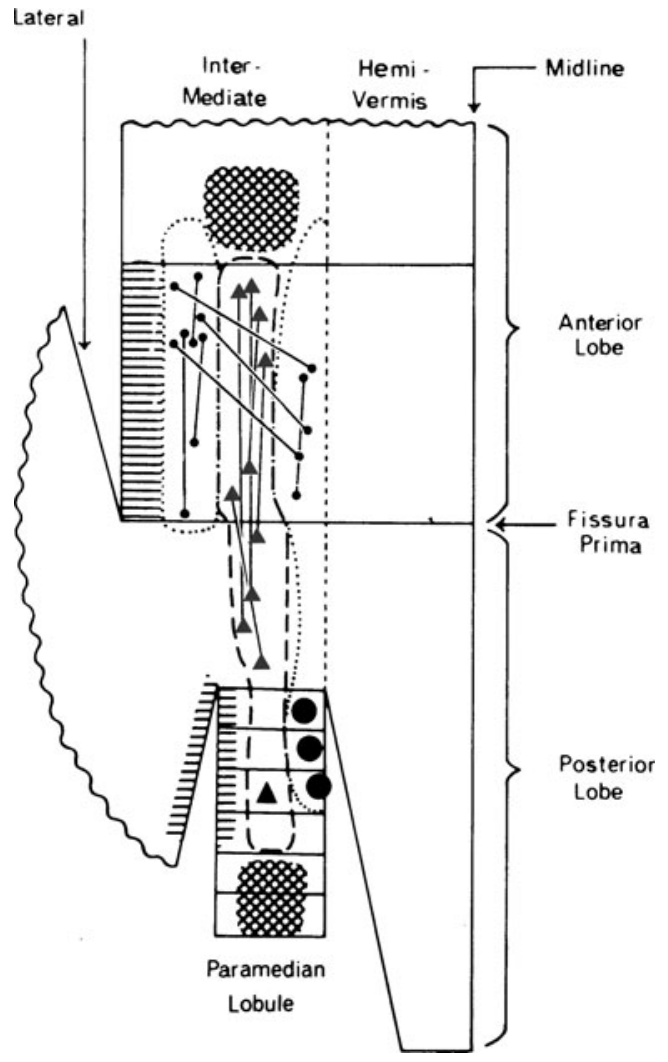

Fig. 12 Distribution of the axon reflex of branching climbing fibers in the cerebellum of the cat. Large symbols indicate stimulation sites; the axon reflex was recorded at the sites of the small symbols. Circles are sites located in the $\mathrm{C}_{1}$ and $\mathrm{C}_{3}$ zones; triangles are located in the $\mathrm{C}_{2}$ zone. Hatching indicates other interconnected sites. Reproduced from Armstrong et al. [63]

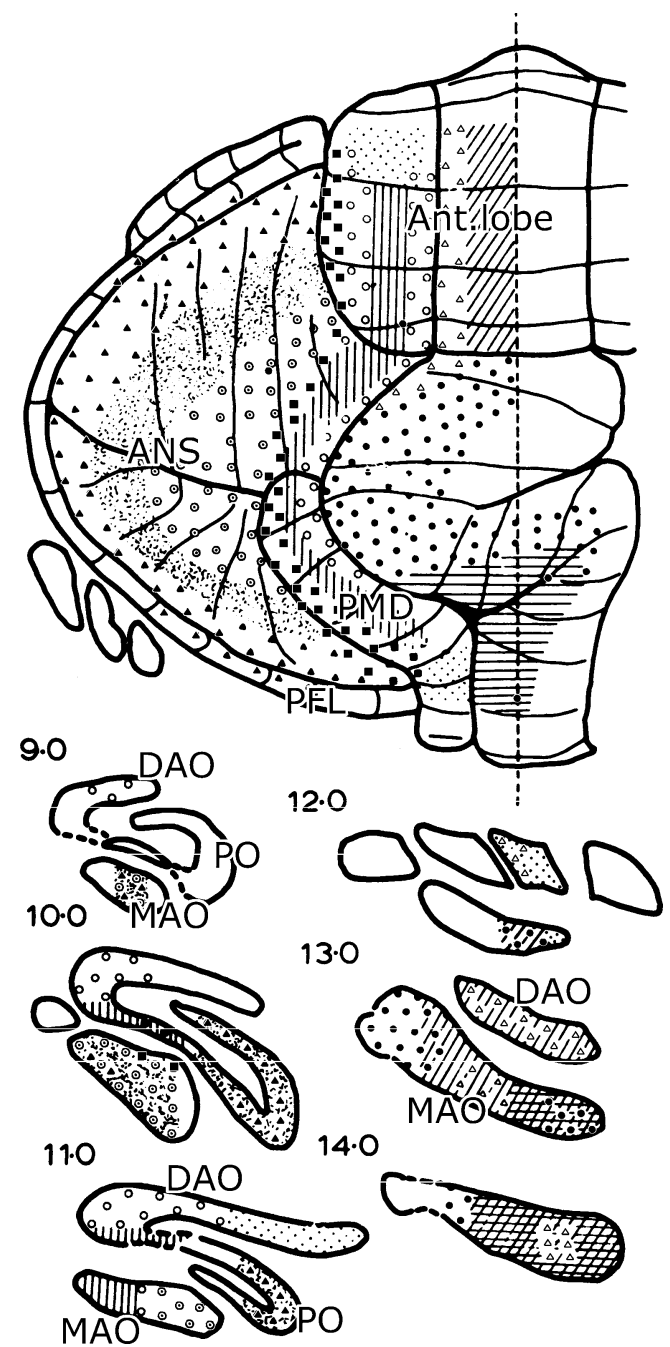

Fig. 13 Diagram of the topographical localization in the olivocerebellar projection in the cat. Reproduced from Armstrong et al. [65]

invited me as a visiting professor after my retirement in 1998 [34]. David Armstrong contributed much to British neurophysiology and his Bristol Department, as a scientist, an editor, a chairman, an educator, and as a member of innumerable committees. Apart from neuroscience, David's interests ranged between the Great War and the demography of his native North England. His life was spent between Bristol and the Northern Isles, settling in the Orkneys after his retirement. One may wonder why Armstrong, Oscarsson, and I didn't set up a grand European research program on the cerebellum, but these possibilities didn't exist at the time where "living apart together" between departments was the rule.

In the 1970s, Enrico Marani introduced histochemistry in the lab. Using acetylcholinesterase histochemistry on unfixed cryostate sections, he showed the accumulation of this enzyme in the molecular layer of the cerebellum of the cat, medial to the $\mathrm{X} / \mathrm{B}$ border [66]. In subsequent studies, 
he re-investigated the longitudinal banding pattern of $5^{\prime}$-nucleotidase in the cerebellar cortex that was first described by Scott in the mouse [67] (Fig. 14). Marani described this pattern in great detail in the rat and concluded from his electron microscopical analysis that it was located in Purkinje cell dendrites [68, 69]. This caused a lasting controversy with Kreutzberg, who stuck to its glial localization [70]. In 1986, I reviewed the chemoarchitecture of the cerebellum, together with Enrico Marani and Dick Jaarsma, whose expertise saved me from a chemical disaster [71].

Exactly the same banding pattern was described some years later by Hawkes and Leclerc in the rat for the Purkinje cell-specific antibody MABQ-113, later known as zebrin [72-74] (Fig. 7a). In subsequent studies, Hawkes and others showed that the zebrin pattern stands for the distribution of a great many of substances located in Purkinje cells, Bergmann glia, and climbing fibers. Moreover, the zebrin pattern turned out to be part of the architecture of the cerebellum in many mammalian species. In a recent collaborative study, we also showed its presence in birds [75]. The impenetrable terminological jungle that resulted from the introduction of different nomenclatures for zebrin bands and corticonuclear and olivocerebellar

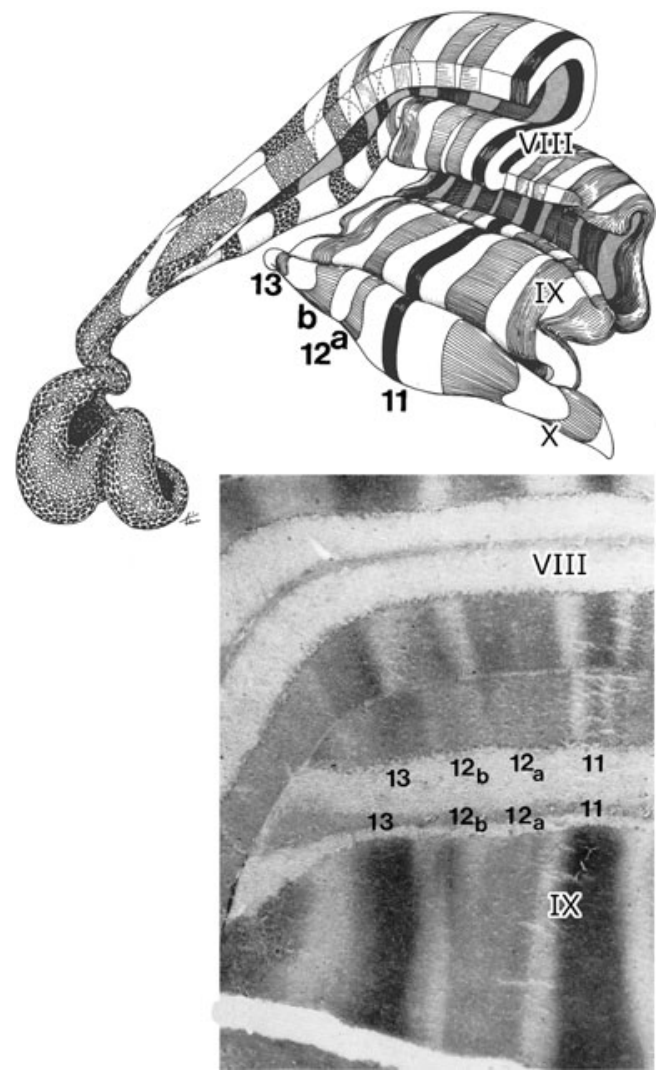

Fig. 14 Distribution of 5 '-nucleotidase in lobules of the posterior lobe of the cerebellum in the mouse. Reproduced from Marani [69]. Drawing by Jan Tinkelenberg projection zones recently was explored by Apps and Hawkes [76].

During a meeting of the Society for Neuroscience, Doug Hess, a Ph.D. student from the MIT, approached me with acetylcholinesterase-stained sections of the macaque and squirrel monkeys cerebellum that clearly showed the borders of the white matter compartments [77]. The main compartments could be identified by their continuity with particular cerebellar nuclei and by the comparison with a limited number of tracing experiments with tritiated amino acid injections in the inferior olive [78] (Fig. 15). These observations confirmed Duane Haines' descriptions of the zonal pattern in monkeys [41]. In general, the zonal organization of the monkey cerebellum appears to be very similar to the cat. Future studies in monkeys, comparing the acetylcholinesterase compartments with zebrin-staining of the Purkinje cell bands, should verify this conclusion. From the recent description of the zebrin II (aldolase C) banding pattern in the marmoset by Sugihara's group [79], such a project would appear to be feasible.

Of course, we were anxious to compare the zebrin pattern to the corticonuclear and olivocerebellar projection zones. This had to wait till the next century, when I was able to show the congruence of these patterns in Bristol, together with Richard Apps, Joanne Pardoe, and Tom Ruigrok [32] and in subsequent papers with Tom Ruigrok and Angelique Pijpers [80, 81]. The next year, our observations were confirmed and extended in similar studies by Sugihara and Shinoda [61, 82], whose extensive material of small injections in the medial accessory olive allowed the distinction of a number of zebrin-positive and -negative subzones in the territory of the A zone.

In 1983, Hans Feirabend published his thesis on the development and the parasagittal compartmentation of the cerebellum of the chicken [83]. He showed how longitudinal Purkinje cell zones develop from superficially located Purkinje cell clusters. This mode of development of the zonal pattern had been shown before by Helge Korneliussen, one of Jan Jansen's students. Surprisingly, he first demonstrated it in the fetal cetacean cerebellum, where the $\mathrm{C}_{2}$ cluster by far exceeded the other prospective zones in size [84] and later for the cerebellum of the rat [85]. In late stages, Feirabend observed that the Purkinje cell clusters became demarcated by strands of migrating granule cells, the "granule cell raphes" [86]. More recently, these structures were recognized and used as topographical markers in histochemical studies on Purkinje cell maturation [87-90]. Using tritiated thymidine to label neurons at the time of their birth, Feirabend demonstrated that Purkinje cells of different clusters are born at different dates [91]. These observations were confirmed by Karam et al. in the chicken [92] and by Hashimoto and Mikoshiba in the mouse [93] (Fig. 7c). The latter recently compared Purkinje 

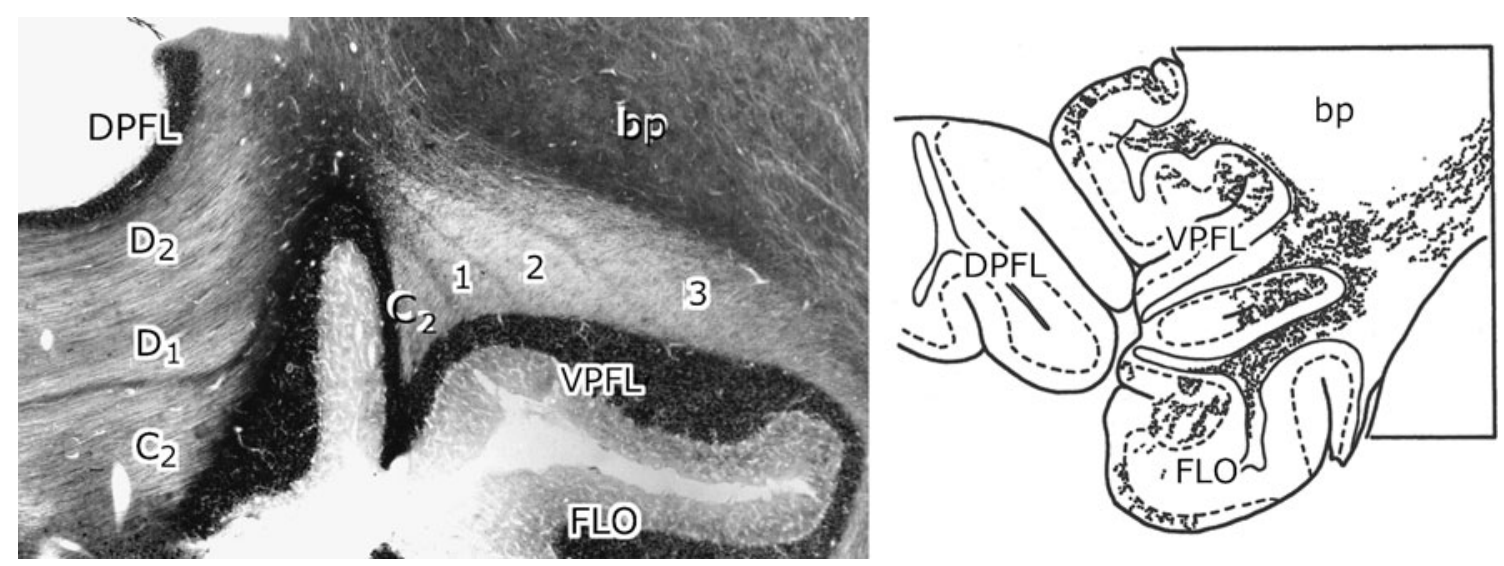

Fig. 15 Left panel the $\mathrm{C}_{2}$ and the floccular compartments $1-3$ in the white matter of the floccular lobe of the rhesus monkey. Acetylcholinesterase staining. Right panel localization of labeled climbing fibers in floccular compartment 2, after an injection of tritiated leucine in the dorsal cap of the rhesus monkey. Reproduced from Gerrits [110] cell birth dates with the zebrin pattern and concluded that Purkinje cells of the zebrin-negative $\mathrm{B}, \mathrm{C}_{1}, \mathrm{C}_{3}$, and $\mathrm{Y}$ zones were born later than those of the zebrin-positive $\mathrm{C}_{2}, \mathrm{D}_{1}$, and $\mathrm{D}_{2}$ zones [31]. A great deal of attention has been devoted to the early development of the zones and the genetic factors involved (Fig. 7b) [94]. They are considered in another chapter in this issue.

Developmental studies of Purkinje cell clusters and their transformation into adult Purkinje cell zones were pursued by Rita Kappel in staged Rhesus monkey fetuses from the collection of Dr. A.A.M. Gribnau at the Department of Anatomy of the Radboud University Nijmegen [95]. Her main conclusions were that the zonal pattern, known from our earlier work in cats and monkeys, also could be recognized in its development in monkeys. Moreover, Purkinje cell clusters of the incipient $\mathrm{A}, \mathrm{C}_{2}$, and $\mathrm{D}$ zones are the first to reach the meningeal surface of the cerebellar anlage. Clusters that will develop into the $\mathrm{B}, \mathrm{C}_{1}$, and $\mathrm{C}_{3}$ zones reach the surface later, penetrating between the earlier arriving clusters (Fig. 16). When considering the long series of our observations on the zones, I am inclined to distinguish at least two kinds of Purkinje cell zones. Purkinje cell axons of the $\mathrm{B}, \mathrm{C}_{1}$, and $\mathrm{C}_{3}$ zones are relatively large, the climbing fibers innervating these zones stem from the dorsal accessory olive, and they transmit information from the peripheral receptors. The Purkinje cells of these zones are zebrin-negative in rodents and are born relatively late in the mouse and arrive late at the cerebellar surface in monkeys. Purkinje cells of the $\mathrm{C}_{2}$ and the $\mathrm{D}$ zones have smaller axons and are innervated by climbing fibers from subdivisions of the olive that receive their input from rostral parts of the brain stem. These Purkinje cells are zebrinpositive, are born early, and are the first to be present at the cerebellar surface. Amazingly, the different phenotypes of Purkinje cells have scarcely received any attention from physiologists. They still consider all Purkinje cells as homogeneous species.

With so much anatomy, one wonders what the function of the modular organization of the cerebellum could be. Our contributions to this question resulted from my move to the Department of Anatomy of the Erasmus University in Rotterdam in 1985. The contrast with Leiden where I spent the past 35 years could not be greater. Leiden is an old, provincial university, where you cultivated friendships with scholars of the Persian language, mathematicians, and biologist and where your children shared the same schools. The Rotterdam medical school was founded by Querido, a Leiden professor of internal medicine, in 1967 as a modern, research-oriented institution, at a time where money was not a problem. I succeeded Hans Kuypers, one of the founding professors of the school, a student of Walle Nauta

Fig. 16 Styropor reconstructions of the anterior aspect of the cerebellar anlage of three rhesus monkey fetuses, showing the emergence of the $\mathrm{B}, \mathrm{C}_{1}$, and $\mathrm{C}_{3}$ Purkinje cell clusters between the early arriving A, $\mathrm{C}_{2}$, and D clusters. From Kappel [94]

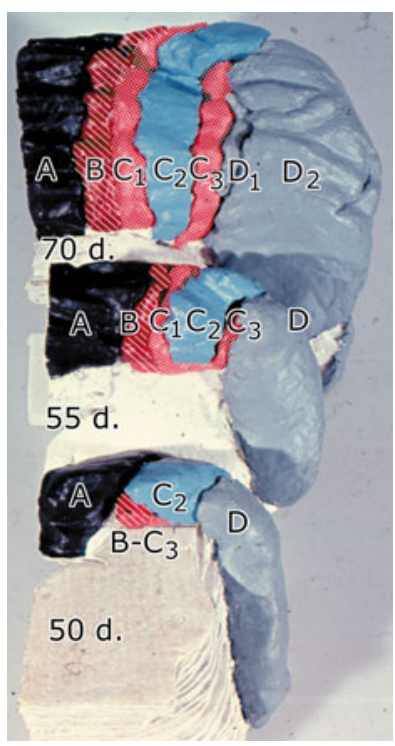


who had spent a long time in the USA where he pursued his prestigious studies on the anatomy of the motor system. He innovated tract tracing, by the introduction of fluorescent tracers and, in his later years, by the use of viruses in transneuronal axonal transport. When he was offered the chair of anatomy in Cambridge in 1985, he eagerly accepted, also to escape the Dutch rules for retirement at the age of 65 . Unfortunately, he had little time left; he died in Cambridge in 1988. In Leiden, in the 1980s, the rule of the senate and the faculties, where membership was restricted to the full professors, was replaced by elected councils and interfering bureaucrats at all levels. The Rotterdam school was managed more effectively; chairmen only negotiated with the director of the school, Jan Groeneveld, and with the dean; student participation hadn't obtained a hold; and the talented but conservative faculty retained their grip.

The Erasmus Medical Center Rotterdam, as it is now called, was an excellent place to work. True, it lacked the coziness of Leiden, but also its conceit. The pleasures of Rotterdam only lasted a short time. After a year, cutbacks by the government, and the wish to extend research in molecular biology and epidemiology, resulted in a reorganization where our department lost half of its staff. Gross anatomy and embryology virtually disappeared, but neuroanatomy could be salvaged. When Henk Visser, the dean who initiated this disaster, announced his plans to me, he ended by predicting that "the department would rise out of its ashes like a phenix." Indeed, we didn't do badly, but the real rise to fame came under my successor Chris de Zeeuw as the chairman of the new department of Neuroscience. With neuroscience as one of its prime assets, the research of the EMCR is rated first among the Dutch medical schools; its clinical research even occupies the first place in the rating of European medical schools by the Times Higher Education Supplement.

Rotterdam was the place where my collaboration with Mitch Glickstein developed, based on our mutual interest in Bolk's comparative studies of the mammalian cerebellum and in the pontine nuclei as a link in an alternative corticocortical pathway [96-99]. Alan Gibson was a less frequent visitor but kept us on our toes with his unconventional ideas about the function of the climbing fibers. Rotterdam was home for Len Eisenman's 1986 sabbatical, where he contributed substantially to our research in the development of cerebellar connections [100]. Living near us, in Warmond, with his family, his wife Robbie contributed as much to the diversity of our culinary skills. Rotterdam saw a new third edition of Nieuwenhuys, van Huijzen, and Voogd The Human Central Nervous System [101] and its Greek, Chinese, and Japanese translations. More recently, in 2008, its fourth edition was published [102], and translations appeared in Italian and Spanish. At a mean age of 80 , we even succeeded in doubling its size.
The involvement of the flocculus in eye movements provides one of the best answers in the search for the function of the zones. Nico Gerrits was the first to chart the zonal organization of climbing fiber projections to the flocculus of the cat [103]. He observed that these projections extend beyond the posterolateral fissure into the neighboring folia of the ventral paraflocculus. In Rotterdam, I was allotted two Ph.D. students from a newly founded fund. One of them was Chris de Zeeuw, my future successor, the other was Joep Tan. Joep Tan studied the connections of the rabbit flocculus, but now using the five white matter compartments present in its white matter and in the adjacent folium of the ventral paraflocculus, as a template (Fig. 17). The most medial compartment corresponds to the $\mathrm{C}_{2}$ zone that is present in the entire cerebellum. More laterally, compartments 1 and 3, and 2 and 4 correspond with two pairs of interdigitizing zones, with similar afferent climbing fiber and efferent vestibular connections [104-106]. At that moment, Jerry Simpson appeared at the scene as a visiting professor at the Department of Physiology of the Erasmus Medical School and a guest of its chairman Han Collewijn. From Simpson's earlier work on the spatial organization of the visual input and output of the inferior olive and experiments conducted with Joep Tan and Hans van der Steen, they found that stimulation in compartments 1 and 3 caused abduction of the ipsilateral eye around an oblique horizontal axis, and a rotation of the contralateral eye around a parallel axis. Stimulation in compartment 2 was associated with eye movements around a vertical axis. The spatial orientation of the rotation axes of the two main classes of evoked eye movements closely correspond to that of the preferred axes of the visual climbing input that carries information on retinal slip to the two pairs of floccular zones. This suggests that both are organized in a similar coordinate system that closely corresponds to that of the semicircular canals [107]. Since the flocculus is known to be involved in the longterm adaptation of eye movement, and the Marr-Ito hypothesis [108] predicts that adaptation depends on simultaneous activation of climbing fiber terminals and the mossy-parallel fiber system on Purkinje cell dendrites, the flocculus apparently functions as a site of cerebellar learning, preserving its zonal organization from earlier vertebrates where the vestibulo-ocular reflex was the main system regulating eye movements [109]. The cooperation with Jerry Simpson laid the basis for the merger of the Rotterdam Departments of Anatomy and Physiology into a Department of Neuroscience, chaired by Chris de Zeeuw.

A very similar compartmental organization was found in the white matter of the flocculus of the monkey with acetylcholinesterase histochemistry (Fig. 15). However, it extended into the entire ventral paraflocculus, and the most lateral compartment 4 appeared to be missing. Tracing the 
climbing fiber projection of the dorsal cap to floccular zone 2 of the monkey, Gerrits [110] showed that the zonal organization of these lobules in monkeys is identical to that in rabbit, cat and, as published later, in rat [111] and mouse [112]. Gerrits also pointed out that in most physiological studies in monkeys, the flocculus was mistaken for the ventral paraflocculus, and that conclusions drawn from comparison of their data with recordings made in the rabbit flocculus, therefore, would be invalid. This lead to shorttime panic among the visual physiologists, but they solved this by using the term "floccular lobe" or "complex" for the two lobules. Nagao suggested that large primate ventral paraflocculus would be engaged in adapting smooth pursuit, whereas the flocculus would have retained its function in adaptation of the vestibule-ocular reflex [113]. This hypothesis could not be confirmed by Rambold and Lisberger [114] who found, instead, that the ventral paraflocculus, rather than the flocculus, was involved in both kinds of eye movements. In my opinion, the nature of the mossy fiber afferent systems, terminating in the floccular lobe, would determine its function in different kind of eye movements. However, the precise distribution of these mossy fiber systems has never been studied either in primates or in lower mammals.

After more than 50 years of research in the zonal organization of the cerebellum, it is gratifying to see that cerebellar studies still are thriving in the three groups that laid the foundations for this concept. Richard Apps studies the behavioral significance of the zones in David Armstrong's old department in Bristol. Carl-Frederik Ekerot and Henrik Jörntell continued their analysis of the microcircuitry of the $\mathrm{C}_{3}$ zone, using patch clamp recording in vivo in Olav Oscarsson's former department in Lund; Tom Ruigrok combines the functional anatomy with a heavy teaching load; and Chris de Zeeuw and his group unravel the molecular biology of cerebellar learning by the flocculus, both in the Department of Neuroscience of the Erasmus Medical Center in Rotterdam.
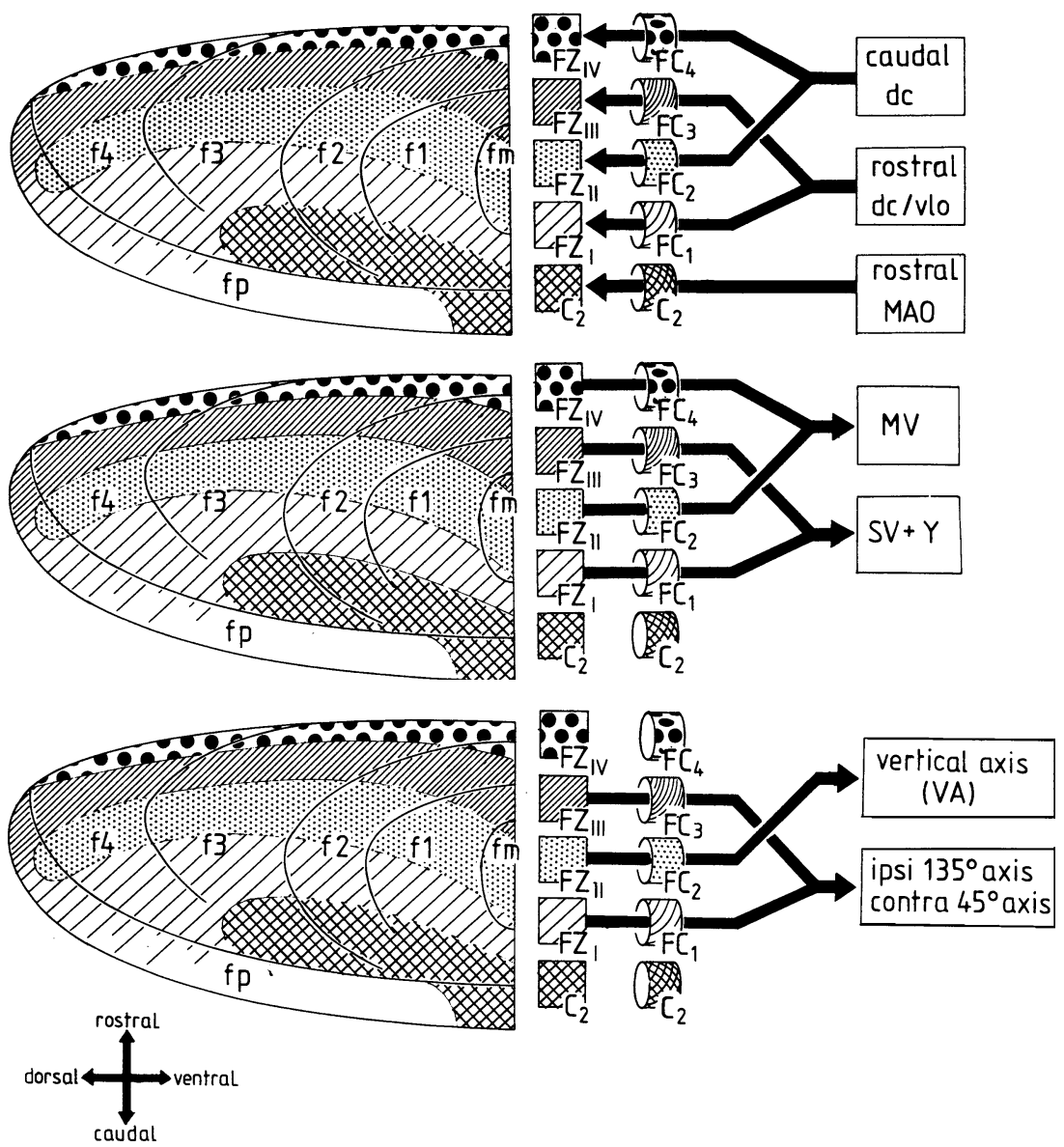

Fig. 17 Diagrams of the zones f1-f4 and $\mathrm{C}_{2}$ of the flocculus of the rabbit, their white matter compartments FC $1-4$ and $\mathrm{C}_{2}$, their climbing fiber afferents (upper panel), their efferent connections (middle panel), and the rotation axes of the eyes on stimulation of compartments FC 1-3 (lower panel). $d c$ dorsal cap, $f m$ ventral folium of the flocculus, $f p$

folium $\mathrm{P}$ of the ventral paraflocculus, $M A O$ medial accessory olive, $M V$ medial vestibular nucleus, $S V$ superior vestibular nucleus, vlo ventrolateral outgrowth, $Y$ group Y. Reproduced from Tan et al. and Van Der Steen et al. [105-107] 
Conflicts of interest I do not have any financial or personal relationships that might bias the work published in this paper.

Open Access This article is distributed under the terms of the Creative Commons Attribution Noncommercial License which permits any noncommercial use, distribution, and reproduction in any medium, provided the original author(s) and source are credited.

\section{References}

1. Alzheimer A. Beiträge zur Kenntnis der pathologischen Glia und ihrer Beziehungen $\mathrm{zu}$ den Abbauprodukten im Nervengewebe. Histologische und histopathologische Arbeiten über die Grosshirnrinde, vol. 3. 1910. p. 3.

2. Romeis B. Mikroskipische Technik. München: Ildenburg; 1948.

3. Blum F. Der Formaldehyd als Härtungsmittel. Zeitschrift für wissneschaftliche Mikroskopie. 1896;10:314.

4. Häggqvist. Analyse der Faserverteilung in einem Rückenmark querschnitt. Z Mikr Anat Forschung. 1936;39:1-34.

5. Mechelse K. De vezelstructuur van de capsula interna en pedunculus cerebri bij Macaca ira. Thesis, Leiden; 1953.

6. Giok SP. Localization of fibre systems within the white matter of the medulla oblongata and the cervical cord in man. Thesis, Leiden; 1956.

7. Busch HFM. An anatomical analysis of the white matter in the brain stem of the cat. Assen: Van Gorcum; 1961.

8. Van Beusekom GT. Fibre analysis of the anterior and lateral funiculi of the cord in the cat. Thesis, Leiden; 1955.

9. Van Crevel H, Verhaart WJC. The "exact" origin of the pyramidal tract. A quantitative study in the cat. JAnat. 1963;97:495-515.

10. Verhaart WJC. The fiber content of the superior cerebellar peduncle in the pons and the mesencephalon. Acta Morphol Neerl Scand. 1956;1:2-8.

11. Brunner H. Die zentrale Kleinhirnkerne bei den Saugetieren. Arb Neurol Inst Wiener Univ. 1919;22:200-71.

12. Jansen J, Brodal A. Aspects of cerebellar anatomy. Oslo: Johan Grundt Tanum Verlag; 1954.

13. Jansen J, Brodal A. Das Kleinhirn. Handbuch der mikroskopischen Anatomie des Menschen IV/8. Berlin: Springer; 1958.

14. Jansen J, Brodal A. Experimental studies on the intrinsic fibers of the cerebellum. II. The corticonuclear projection. J Comp Neurol. 1940;73:267-321.

15. Jansen J, Brodal A. Experimental studies on the intrinsic fibers of the cerebellum. III. Corticonuclear projection in the rabbit and the monkey. Norske Vid Akad Avh 1 Math Nat K1. 1942;3:1-50.

16. Weidenreich F. Zur Anatomie der zentralen Kleinhirnkerne der Säuger. Z Morphol Anthropol. 1899;1:259-312.

17. Ogawa T. Beiträge zur vergleichenden Anatomie des Zentralnervensystems der Wassersaugetiere: Ueber die Kleinhirnkerne per Pinnipedien und Cetaceen. Arb Anat Inst Sendai. 1935; 17:63-136.

18. Busch HFM. Anatomical aspects of the anterior and lateral funiculi at the spino-bulbar junction. Prog Brain Res. 1964;11:223-37.

19. Voogd J. The cerebellum of the cat: Structure and fiber connections. Thesis, Leiden. Assen: van Gorcum; 1964.

20. Bolk L. Das cerebellum der Saugetiere. Jena: Bohn-Fischer; 1906.

21. Dankmeijer J, Nauta WJH. Experiments with the protargol stain of nerve fibers according to Bodian. Ned Tschr Geneesk. 1939;83:3846-7.

22. Van Rossum J. Corticonuclear and corticovestibular projections of the cerebellum. An experimental investigation of the anterior lobe, the simple lobule and the caudal vermis of the rabbit. Thesis, Leiden; 1969
23. Matsushita M, Wang CL. Projection pattern of vestibulocerebellar fibers in the anterior vermis of the cat: an anterograde wheat germ agglutinin-horseradish peroxidase study. Neurosci Lett. 1987;74:25-30.

24. Serapide MF, Panto MR, Parenti R, Zappala A, Cicirata F. Multiple zonal projections of the basilar pontine nuclei to the cerebellar cortex of the rat. J Comp Neurol. 2001;430:471-84.

25. Wu HS, Sugihara I, Shinoda Y. Projection patterns of single mossy fibers originating from the lateral reticular nucleus in the rat cerebellar cortex and nuclei. J Comp Neurol. 1999;411:97-118.

26. Voogd J, Broere G, van Rossum J. The medio-lateral distribution of the spinocerebellar projection in the anterior lobe and the simple lobule in the cat and a comparison with some other afferent fiber systems. Psych Neurol Neurochir. 1969;72:137-51.

27. Pijpers A, Apps R, Pardoe J, Voogd J, Ruigrok TJ. Precise spatial relationships between mossy fibers and climbing fibers in rat cerebellar cortical zones. J Neurosci. 2006;26:12067-80.

28. Vielvoye GJ, Voogd J. Time dependence of terminal degeneration in spino-cerebellar mossy fiber rosettes in the chicken and the application of terminal degeneration in successive degeneration experiments. J Comp Neurol. 1977;175:233-42.

29. Grofova I. Ansa and fasciculus lenticularis of carnivora. J Comp Neurol. 1970;138:195-208.

30. Voogd J. The importance of fiber connections in the comparative anatomy of the mammalian cerebellum. In: Llinas R, editor. Neurobiology of cerebellar evolution and development. Chicago: AMA-ERF Institute for Biomedical Research; 1969. p. 493-514.

31. Hashimoto M. Striking correlation between cerebellar compartments determined by the birthdate of Purkinje cells and zebrin II bands. Soc Neurosi Abstracts. 2010;231 5/A5.

32. Voogd J, Pardoe J, Ruigrok TJ, Apps R. The distribution of climbing and mossy fiber collateral branches from the copula pyramidis and the paramedian lobule: congruence of climbing fiber cortical zones and the pattern of zebrin banding within the rat cerebellum. J Neurosci. 2003;23:4645-56.

33. Desclin JC. Histological evidence supporting the inferior olive as the major source of cerebellar climbing fibers in the rat. Brain Res. 1974;77:365-88.

34. Brodal A. Experimentelle Untersuchungen über die OlivoCerebellaren Lokalization. Z Neurol. 1940;169:1-53.

35. Groenewegen HJ, Voogd J. The parasagittal zonation within the olivocerebellar projection. I. Climbing fiber distribution in the vermis of cat cerebellum. J Comp Neurol. 1977;174:417-88.

36. Groenewegen HJ, Voogd J, Freedman SL. The parasagittal zonation within the olivocerebellar projection. II. Climbing fiber distribution in the intermediate and hemispheric parts of cat cerebellum. J CompNeurol. 1979;183:551-602.

37. Courville J, Faraco-Cantin F, Diakiw N. A functionally important feature of the distribution of the olivo-cerebellar climbing fibers. Can J Physiol Pharmacol. 1974;52:1212-7.

38. van der Want JJL, Voogd J. Ultrastructural identification and localization of climbing fiber terminals in the fastigial nucleus of the cat. J Comp Neurol. 1987;258:81-90.

39. van der Want JJL, Wiklund L, Guegan M, Ruigrok T, Voogd J. Anterograde tracing of the rat olivocerebellar system with Phaseolus vulgaris-leucoagglutinin (PHA-L). Demonstration of climbing fiber collateral innervation of the cerebellar nuclei. J Comp Neurol. 1989;288:1-18.

40. Ruigrok TJ, Voogd J. Organization of projections from the inferior olive to the cerebellar nuclei in the rat. J Comp Neurol. 2000;426:209-28.

41. Haines DE, Patrick GW, Satrulee P. Organization of cerebellar corticonuclear fiber systems. Exp Brain Res. 1982;( Suppl 6): 320-67.

42. Bigaré F. De efferente verbindingen van de cerebellaire schors bij de kat. Thesis, Leiden; 1980. 
43. Voogd J, Bigaré F. Topographical distribution of olivary and cortico nuclear fibers in the cerebellum: a review. In: Courville J, de Montigny C, Lamarre Y, editors. The inferior olivary nucleus anatomy and physiology. New York: Raven; 1980. p. 207-34.

44. Graybiel AM, Nauta HJW, Lasek RJ, Nauta WJH. Experimental anatomical evidence for a cerebello-olivary pathway in the cat. Anat Rec. 1973;175:332.

45. Ruigrok TJH, Voogd J. Cerebellar nucleo-olivary projections in rat. An anterograde tracing study with Phaseolus vulgarisleucoagglutinin (PHA-L). J Comp Neurol. 1990;298:315-33.

46. Larsell O, Jansen J. The comparative anatomy and histology of the cerebellum. The human cerebellum, cerebellar connections, and the cerebellar cortex. Minneapolis: University of Minnesota Press; 1972.

47. Brodal A, Kawamura K. Olivocerebellar projection: a review. Adv Anat Embryol Cell Biol. 1980;64:1-137.

48. Llinás R. Neurobiology of cerebellar evolution and development. Chicago: AMA; 1969.

49. Oscarsson O. Termination and functional organization of a dorsal spino-olivocerebellar path. Brain Res. 1967;5:531-4.

50. Oscarsson $\mathrm{O}$. Termination and functional organization of the ventral spino-olivocerebellar path. J Physiol (Lond). 1968;196:453-78.

51. Oscarsson $\mathrm{O}$. The sagittal organization of the cerebellar anterior lobe as revealed by the projection patterns of the climbing fiber system. In: Llinas R, editor. Neurobiology of cerebellar evolution and development. Chicago: AMA-ERF; 1969. p. 525-37.

52. Andersson G, Oscarsson O. Climbing fiber microzones in cerebellar vermis and their projection to different groups of cells in the lateral vestibular nucleus. Exp Brain Res. 1978;32:565-79.

53. Andersson G, Eriksson L. Spinal, trigeminal, and cortical climbing fibre paths to the lateral vermis of the cerebellar anterior lobe in the cat. Exp Brain Res. 1981;4:71-81.

54. Ekerot CF, Larson B. The dorsal spino-olivocerebellar system in the cat. II. Somatotopical organization. Exp Brain Res. 1979;36:219-32.

55. Ekerot CF, Larson B. The dorsal spino-olivocerebellar system in the cat. I. Functional organization and termination in the anterior lobe. Exp Brain Res. 1979;36:201-17.

56. Ekerot CF, Larson B. Branching of olivary axons to innervate pairs of sagittal zones in the cerebellar anterior lobe of the cat. Exp Brain Res. 1982;48:185-98.

57. Campbell NC, Armstrong DM. Origin in the medial accessory olive of climbing fibres to the $\mathrm{x}$ and lateral $\mathrm{c} 1$ zones of the cat cerebellum: a combined electrophysiological/WGA-HRP investigation. Exp Brain Res. 1985;58:520-31.

58. Buisseret-Delmas C, Yatim N, Buisseret P, Angaut P. The X zone and CX subzone of the cerebellum in the rat. Neurosci Res. 1993;16:195-207.

59. Trott JR, Armstrong DM. The cerebellar corticonuclear projection from lobule $\mathrm{Vb} / \mathrm{c}$ of the cat anterior lobe: a combined electrophysiological and autoradiographic study. I. Projections from the intermediate region. Brain Res. 1987;66:318-38.

60. Buisseret-Delmas C, Angaut P. Sagittal organization of the olivocerebellonuclear pathway in the rat. III. Connections with the nucleus dentatus. Neurosci Res. 1989;7:131-43.

61. Sugihara I, Shinoda Y. Molecular, topographic, and functional organization of the cerebellar cortex: a study with combined aldolase C and olivocerebellar labeling. J Neurosci. 2004;24:8771-85.

62. Sugihara I, Shinoda Y. Molecular, topographic and functional organization of the cerebellar nuclei: analysis by threedimensional mapping of the olivonuclear projection and aldolase C labeling. J Neurosci. 2007;27:9696-710.

63. Armstrong DM, Harvey RJ, Schild RF. The spatial organisation of climbing fibre branching in the cat cerebellum. Exp Brain Res. 1973;18(1):40-58.
64. Armstrong DM, Harvey RJ, Schild RF. Cerebello-cerebellar responses mediated via climbing fibres. Exp Brain Res. 1973;18:19-39.

65. Armstrong DM, Harvey RJ, Schild RF. Topographical localization in the olivo-cerebellar projection: an electrophysiological study in the cat. J CompNeurol. 1974;154:287-302.

66. Marani E, Voogd J. An acetylcholinesterase band-pattern in the molecular layer of the cat cerebellum. J Anat. 1977;124:335-45.

67. Scott TG. An unique pattern of localization within the cerebellum. Nature. 1963;200:793.

68. Marani E. The subcellular distribution of 5'-nucleotidase activity in mouse cerebellum. Exp Neurol. 1977;57:1042-8.

69. Marani E. Topographic histochemistry of the cerebellum. Prog Histol Cytochem. 1986;16:1-169.

70. Schoen SW, Graeber MB, Reddington M, Kreutzberg GW. Light and electron microscopical immunocytochemistry of 5'-nucleotidase in rat cerebellum. Histochemistry. 1987;87:107-13.

71. Voogd J, Jaarsma D, Marani E. The cerebellum: chemoarchitecture and anatomy. In: Swanson LW, Björklund A, Hökfelt T, editors. Handbook of chemical neuroanatomy. Amsterdam: Elsevier; 1996. p. 1-369.

72. Hawkes R, Colonnier M, LeClerc N. Monoclonal antibodies reveal sagittal banding in the rodent cerebellar cortex. Brain Res. 1985;333:359-65.

73. Hawkes R, Leclerc N. Antigenic map of the rat cerebellar cortex: the distribution of parasagittal bands as revealed by monoclonal antiPurkinje cell antibody mabQ113. J Comp Neurol. 1987;256:29-41.

74. Eisenman LM, Hawkes R. 5'-Nucleotidase and the mabQ113 antigen share a common distribution in the cerebellar cortex of the mouse. Neuroscience. 1989;31:231-5.

75. Marzban H, Chung SH, Pezhouh MK, Feirabend H, Watanabe $\mathrm{M}$, Voogd J, et al. Antigenic compartmentation of the cerebellar cortex in the chicken (Gallus domesticus). J Comp Neurol. 2010;518:2221-39.

76. Apps R, Hawkes R. Cerebellar cortical organization: a one-map hypothesis. Nat Rev Neurosci. 2009;10:670-81.

77. Hess DT, Voogd J. Chemoarchitectonic zonation of the monkey cerebellum. Brain Res. 1986;369:383-7.

78. Voogd J, Gerrits NM, Hess DT. Parasagittal zonation of the cerebellum in macaques: an analysis based on acetylcholinesterase histochemistry. In: Glickstein M, Yeo C, Stein J, editors. Cerebellum and neuronal plasticity. New York: Plenum Publishing Corporation; 1987. p. 15-39.

79. Fujita H, Oh-Nishi A, Obayashi S, Sugihara I. Organization of the marmoset cerebellum in three-dimensional space: lobulation, aldolase C compartmentalization and axonal projection. J Comp Neurol. 2010;518:1764-91.

80. Pijpers A, Voogd J, Ruigrok TJ. Topography of olivo-corticonuclear modules in the intermediate cerebellum of the rat. $\mathrm{J}$ Comp Neurol. 2005;492:193-213.

81. Voogd J, Ruigrok TJ. The organization of the corticonuclear and olivocerebellar climbing fiber projections to the rat cerebellar vermis: the congruence of projection zones and the zebrin pattern. J Neurocytol. 2004;33:5-21.

82. Sugihara I, Quy PN. Identification of aldolase C sompartments in the mouse cerebellar cortex by olivocerebellar labeling. J Comp Neurol. 2007;500:1076-92.

83. Feirabend HKP. Anatomy and development of longitudinal patterns in the architecture of the cerebellum of the white leghorn (Gallus domesticus). Thesis, Leiden; 1983.

84. Korneliussen HK. Cerebellar corticogenesis in Cetaca, with special reference to regional variations. J Hirnforsch. 1967;9:151-585.

85. Korneliussen HK. On the ontogenetic development of the cerebellum (nuclei, fissures, and cortex) of the rat, with special reference to regional variations in corticogenesis. J Hirnforsch. $1968 ; 10: 379-412$. 
86. Feirabend HK. Development of longitudinal patterns in the cerebellum of the chicken (Gallus domesticus): a cytoarchitectural study on the genesis of cerebellar modules. Eur J Morphol. 1990;28:169-223.

87. Karam SD, Kim YS, Bothwell M. Granule cells migrate within raphes in the developing cerebellum: an evolutionarily conserved morphogenic event. J Comp Neurol. 2001;440:127-35.

88. Lin JC, Cepko CL. Granule cell raphes and parasagittal domains of Purkinje cells: complementary patterns in the developing chick cerebellum. J Neurosci. 1998;18:9342-53.

89. Luckner R, Obst-Pernberg K, Hirano S, Suzuki ST, Redies C. Granule cell raphes in the developing mouse cerebellum. Cell Tissue Res. 2001;303:159-72.

90. Redies C, Luckner R, Arndt K. Granule cell raphes in the cerebellar cortex of chicken and mouse. Brain Res Bull. 2002;57:341-3.

91. Feirabend HK, van Luxemburg EA, van Denderen-van Dorp H, Voogd J. A 3H-thymidine autoradiographic study of the development of the cerebellum of the White Leghorn (Gallus domesticus): evidence for longitudinal neuroblast generation patterns. Acta Morph Neerl -Scand. 1985;23:115-26.

92. Karam SD, Burrows RC, Logan C, Koblar S, Pasquale EB, Bothwell M. Eph receptors and ephrins in the developing chick cerebellum: relationship to sagittal patterning and granule cell migration. J Neurosci. 2000;20:6488-500.

93. Hashimoto M, Mikoshiba K. Mediolateral compartmentalization of the cerebellum is determined on the "birth date" of Purkinje cells. J Neurosci. 2003;23:11342-51.

94. Oberdick J, Schilling K, Smeyne RJ, Corbin JG, Bocchiaro C, Morgan JI. Control of segment-like patterns of gene expression in the mouse cerebellum. Neuron. 1993;10:1007-18.

95. Kappel RM. The development of the cerebellum in Macaca mulatta. A study of regional differences during corticogenesis. Thesis, Leiden; 1981.

96. Glickstein M, Gerrits N, Kraij-Hans I, Mercier B, Stein J, Voogd J. Visual pontocerebellar projections in the macaque. J Comp Neurol. 1994;349:51-72.

97. Glickstein M, Voogd J. Lodewijk Bolk and the comparative anatomy of the cerebellum. Trends Neurosci. 1995;18:206-10.

98. Voogd J, Glickstein M. The anatomy of the cerebellum. Trends Neurosci. 1998;21:370-5.

99. Glickstein M, Sultan F, Voogd J. Functional localization in the cerebellum. Cortex. 2009. doi:10.1016/j.cortex.2009.09.001.

100. Eisenman LM, Schalekamp MP, Voogd J. Development of the cerebellar cortical efferent projection: an in vitro antegrade tracing study in rat brain slices. Brain Res Dev Brain Res. 1991;60:261-6.

101. Nieuwenhuys R, van Huijzen C, Voogd J. The human central nervous system. A synopsisi and atlas. 3rd ed. Berlin: Springer; 1988.

102. Nieuwenhuys R, van Huijzen C, Voiogd J. The human central nervous system. 4th ed. Berlin: Springer; 2008.

103. Gerrits NM, Voogd J. The climbing fiber projection to the flocculus and adjacent paraflocculus in the cat. Neurosci. 1982;7:2971-91.

104. De Zeeuw CI, Wylie DR, DiGiorgi PR, Simpson JI. Projections of individual Purkinje cells of identified zones in the flocculus to the vestibular and cerebellar nuclei in the rabbit. J Comp Neurol. 1994;349:428-47.

105. Tan J, Gerrits NM, Nanhoe R, Simpson JI, Voogd J. Zonal organization of the climbing fiber projection to the flocculus and nodulus of the rabbit: a combined axonal tracing and acetylcholinesterase histochemical study. J Comp Neurol. 1995;356:23-50.

106. Tan J, Simpson JI, Voogd J. Anatomical compartments in the white matter of the rabbit flocculus. J Comp Neurol. 1995;356:1-22.

107. van der Steen J, Simpson JI, Tan J. Functional and anatomic organization of three-dimensional eye movements in rabbit cerebellar flocculus. J Neurophysiol. 1994;72:31-46.

108. Ito M. Cerebellar control of the vestibulo-ocular reflex - around the flocculus hypothesis. Ann Rev Neurosci. 1982;5:275-96.

109. Voogd J, Wylie DR. Functional and anatomical organization of floccular zones: a preserved feature in vertebrates. J Comp Neurol. 2004;470:107-12.

110. Gerrits NM, Voogd J. The topographical organization of climbing and mossy fiber afferents in the flocculus and the ventral paraflocculus in rabbit, cat and monkey. In: Strata P, editor. The olivocerebellar system in motor control. Berlin: Springer; 1989. p. 26-9.

111. Ruigrok TJH, Osse R-J, Voogd J. Organization of inferior olivary projections to the flocculus and ventral paraflocculus of the rat cerebellum. J Comp Neurol. 1992;316:129-50.

112. Schonewille M, Luo C, Ruigrok TJ, Voogd J, Schmolesky MT, Rutteman M, et al. Zonal organization of the mouse flocculus: physiology, input, and output. J Comp Neurol. 2006;497:670-82.

113. Nagao S. Different roles of flocculus and ventral paraflocculus for oculomotor control in the primate. NeuroReport. 1992;3:13-6.

114. Rambold H, Churchland A, Selig Y, Jasmin L, Lisberger SG. Partial ablations of the flocculus and ventral paraflocculus in monkeys cause linked deficits in smooth pursuit eye movements and adaptive modification of the VOR. J Neurophysiol. 2002;87:912-24. 